\title{
THE POMPILINA COMPLEX OF THE GENUS TENTHREDO LINNAEUS (HYMENOPTERA: SYMPHYTA: TENTHREDINIDAE)
}

\author{
M.S. Saini and V. Vasu
}

Department of Zoology, Punjabi University, Patiala, Punjab 147002, India

(web supplement 1647 i-viii)

\begin{abstract}
The pompilina complex of the genus Tenthredo Linnaeus is solved which is now represented by eighteen species. Of these twelve species, namely, infucubitus, fuscoventris, breviantennata, dif, ifa, foveolata, fuscotibiae, breviantennata, equitarsus, picfa, acclivata, and kulwantae added new to science from India are described and illustrated on a uniform systematic pattern. Following this pattern the already known species viz. frontatus Malaise, pseudofrontatus Singh \& Saini, dalhousiensis Singh et al., santokhi Singh \& Saini, serraflata Singh et al. and pompilina Malaise, are redescribed and illustrated. The taxonomic validity of these species has been supported by taxonomic description, illustrations, ecological affinities and detailed discussion. The male counter part of $T$. dalhousiensis Singh et al. whereas the female counter part of T. santokhi Singh \& Saini are associated with their respective opposite sexes. A key to the species of the pompilina complex of the genus Tenthredo Linnaeus is provided.
\end{abstract}

\section{KEYWORDS}

Hymenoptera, pompilina complex, Tenthredinidae, Tenthredo

\section{AbBreViations}

EL - Eye length; FR - Frontal ridge; IATS - Inner apical tibial spur; ICD - Inter cenchri distance; IDMO - Interoocular distance at level of median ocellus; ITD - Inter tegular distance; LID - Lower interocular distance; M - Median cell; MB - Metabasitarsus; MF - Median fovea; OATS - Outer apical tibial spur; OCL - Oculooccipital line; OOL - Oculoocellar line; POL - Postocellar line

In a series of works concerning the revision of Indian Tenthredinidae, the pompilina-complex of the genus Tenthredo Linnaeus is broken into eighteen valid species. Prior to this work, only 170 valid species of this genus were on record from the faunistic limits of India. Of these, only six species belonged to the pompilina-group of this genus from the Indian subcontinent. The contribution, particularly concerned with the addition of several new species and also pertaining to the correct taxonomic placement of certain species along with tracing out several synonymies and homonymies as well, goes to Radoszkowsky (1872), Cameron (1876, 1877, 1899, 1902), Smith (1878), Kirby (1882), Mocsary (1883), Jakovlev (1891), Konow (1898, 1901, 1903, 1905, 1906, 1907, 1908), Rohwer (1915, 1916, 1921), Malaise (1934, 1945), Muche (1982, 1983, 1986), Togashi (1987), Saini and Bharti (1996, 1997ab), Taeger and Blank (1996), Saini \& Vasu (1998ab, 1999, 2001), Saini et al. (1998ab), Singh (1985), Singh et al. (1985ab), Singh and Saini (1987abcd, 1988abcd, 1990, 1994, 1995), Vasu (1998, 2001), Vasu and Chambal (1997, 1998ab), and, Vasu and Saini (1997, 1998, 1999ab). The present text deals with the description and illustration of 12 new and systematic redescription of already known six species of the pompilina-complex of the genus Tenthredo Linnaeus from India.

Among the members of the subfamily Tenthredinidae, species belonging to Tenthredo Linnaeus are characterized by the following combination of features: forewing with straight crossvein in anal cell, hindwing with two closed M cells, clypeus emarginated, and propodeum with mid-longitudinal furrow dividing it into two equal parts. Besides, the members of the pompilina-complex can be identified as: body with at least a part of abdomen or thorax without metallic luster, antenna with unicoloured flagellum, and wings normal, forewing with infuscated band over stigma or only second cubital cell infuscated.

The terminology used in this text is after Ross $(1937,1945)$ and Malaise (1945). The type materials of these species are housed at Division of Entomology, Pusa National Collections, Indian Agricultural Research Institute, New Delhi, India.

\section{Tenthredo infucubitus sp. nov.}

(Figs. 1-6)

\section{Material examined}

Holotype: Female, 3.vii.1984, Jammu \& Kashmir, Pahalgam, 2000m, coll. M.S. Saini.

Paratypes: One male, 3.vii.1984, Jammu \& Kashmir, Pahalgam, 2000m, coll. M.S. Saini; one male, 30.vii.1982, Kalatop, Himachal Pradesh, 2400m, coll. M.S. Saini; one male, 1.vi.1991, Kothi, 2650m, coll. A. Singh; four females, four males, 22.vi.1991, Binayak, Uttaranchal, 2500m, coll. V. Vasu; one male, 26.vii.1993, Gobind Dham, 2900m, coll. V. Vasu; one male, 16.vii.1994, Mandal, 2400m, coll. M.S. Saini; one male, 30.iv.1986, Darjeeling, West Bengal, 2200m, coll. M.S. Saini; one male, 15.iv.1992, Bomdila, Arunachal Pradesh, 2500m, coll. A. Singh.

Individual variation: Tegula entirely pale, mesotibia pale brownish more or less.

\section{Distribution}

India: Arunachal Pradesh, Jammu \& Kashmir, Himachal Pradesh, Uttaranchal, West Bengal.

\section{Etymology}

Species is named after infumated second cubital cell. 

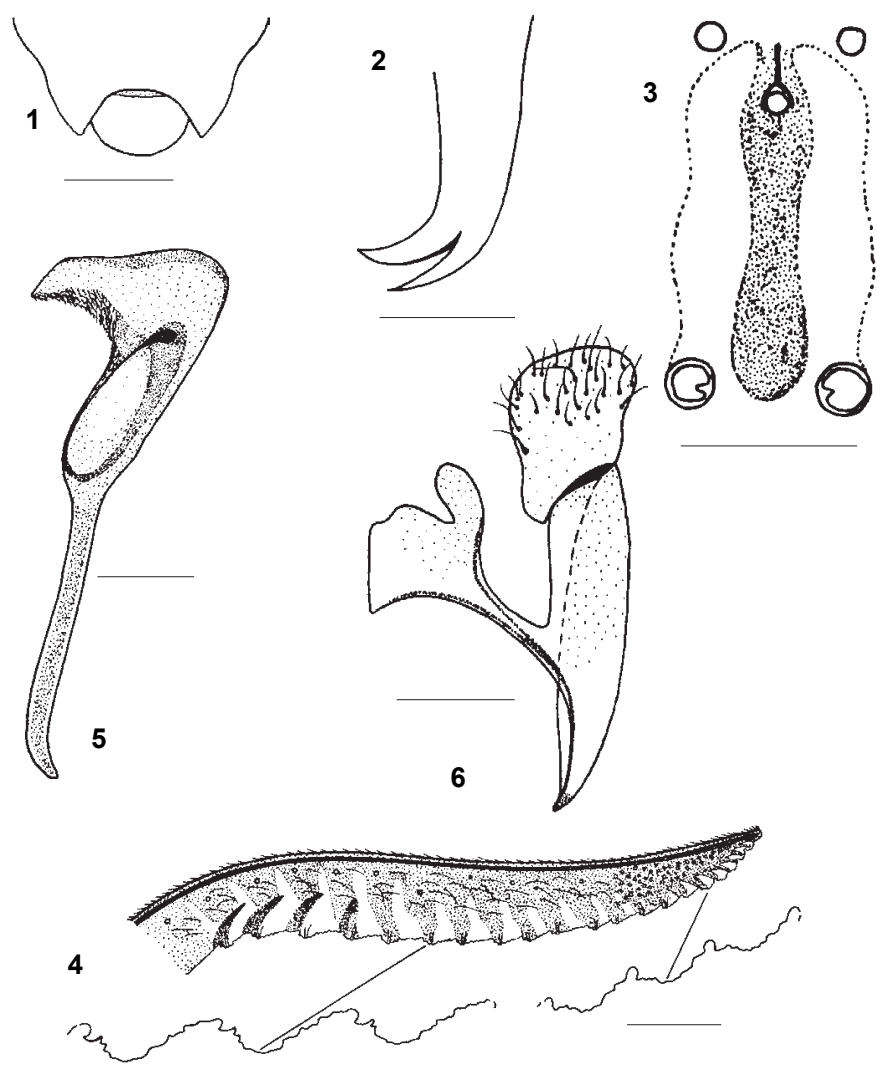

Figs. 1-6. Tenthredo infucubitus sp. nov. 1 - Clypeus and labrum; 2 - Tarsal claw; 3 - Median fovea (front view); 4 - Lancet; 5 - Penis valve; 6 - Gonoforceps. Scale $=1.0 \mathrm{~mm}$

\section{Diagnostic features}

Tenthredo infucubitus belongs to a subgroup of species in which the forewings have the second cubital cell infuscated only and therefore falls far apart from the subgroup having infuscated band below stigma. On the basis of some taxonomically significant key characters such as: narrow posterior and broad lateral margins of propodeum, lateral margin of tergite four, posterior half of tergite nine, sternite four whitish; antenna $2.5 \mathrm{x}$ head width, scape and pedicel as 4:3, segment three shorter than four; postocellar area wider than long as 4:3, with distinct transverse carina on hypothetical hind margin of head; postocellar furrows absent, lateral furrows parallel; median fovea broad, shallow and clearly reaching median ocellus; metafemur equal to metatibia, metabasitarsus equal to following three joints combined, tarsal claw with subapical tooth longer than apical one; IATS:OATS $=1.0: 0.7$, and lancet having 22 serrulae, Tenthredo infucubitus sp. nov. keeps itself distinctly far apart from all other species of its own subgroup as well as other Indian and Oriental species described under this genus so far.

\section{Female}

Colour: Body black, whitish are: clypeus except base, labrum, mandible barring apex, triangular spot on lower hind orbit; narrow posterodorsal, ventral and posterolateral margins of pronotum; inner and outer margins of tegula, ridges lateral to scutelli, margins of mesoscutellar appendage, spot behind metascutellum; narrow posterior and broad lateral margins of propodeum, lateral margin of tergite four, posterior half of tergite nine, sternite four; procoxa except base, anterior stripe on rest of proleg; apex of mesocoxa, anterior stripe on apical half of mesofemur to rest of leg. Wings hyaline with infumated second cubital cell of forewing; venation including costa, subcosta and stigma fuscous.

Structure: Length $8.5 \mathrm{~mm}$. Antenna filiform, $2.5 \mathrm{x}$ head width, flagellum with apical five segments compressed, scape and pedicel as 4:3, segments three and four as 8:9; clypeus (Fig. 1) roundly incised up to $1 / 3$ of its length with pointed lateral teeth, labrum (Fig. 1) wider than long as 5:4 with rounded anterior margin; malar space $0.25 \mathrm{x}$ diameter of median ocellus; LID:IDMO:EL=1.0:1.9:1.6, POL:OCL:OOL=1.0:1.6:2.0; frontal area below level of eyes; median fovea (Fig. 3) broadly canaliculate, clearly reaching median ocellus; supraantennal tubercles low lying and confluenting with similar frontal ridges; postocellar furrow absent, inter- and circumocellar furrows distinct; lateral furrows distinct, parallel; postocellar area subconvex, wider than long as 3:2 and with posterior horizontal carina; head narrowing behind eyes; ICD:ITD $=1.0: 3.0$; mesoscutellum subconvexly round, appendage carinate; mesepisternum obtusely round, mesosternum lacking thorns; metafemur equal to metatibia, metabasitarsus equal to following three joints combined, tarsal claw (Fig. 2) with subapical tooth longer than apical one; IATS:MB:OATS $=1.0: 1.5: 0.7$. Lancet (Fig. 4) having 22 serrulae.

Sculpture: Head shining with scattered, shallow punctures more prominent, dense, minute but distinct on frontal ridges; mesonotum with dense, minute, distinct punctures; mesoscutellum with dense, large, deep, distinct punctures mainly on posterior slope, its appendage with scattered, distinct punctures; mesepisternum with dense, minute, deep, almost confluenting punctures more prominent on its convexity; mesosternum shining, densely punctulate; abdomen faintly microstriated with scattered, fine, shallow punctures, surface subshining.

Pubescence: Silvery, $0.15 x$ scape length.

\section{Male}

Average length $6.0 \mathrm{~mm}$. Similar to female except pale whitish in addition are: clypeus entirely, anterior margin of tergite three, anterior half of tergite four, deflexed lateral sides of tergites two to four, sternites two to five; whitish on legs more prominent with anterior aspects of coxa, trochanter and femur of mesoleg, and anterolateral aspect of coxa, entire trochanter and ventral of femur of metaleg. Genitalia: penis valve (Fig. 5), gonoforceps (Fig. 6).

\section{Tenthredo frontatus Malaise ${ }^{\mathrm{w}}$ (Images $1-5^{\mathrm{w}}$ )}

${ }^{w}$ Text and Images in the web supplement at www.zoosprint.org 


\section{Tenthredo pseudofrontatus Singh \& Saini ${ }^{w}$}

(Images 6-9 ${ }^{\mathrm{w}}$ )

w Text and Images in the web supplement at www.zoosprint.org

\section{Tenthredo fuscoventris sp. nov.}

(Figs. 7-11)

\section{Material examined}

Holotype: Male, 23.vi.1985, Gobindghat, Uttaranchal, 2000m, coll. M.S. Saini.

\section{Etymology}

Species name is after its abdomen with general fuscous colour.

\section{Diagnostic features}

Belonging to the species of pompilina-complex, Tenthredo fuscoventris sp. nov. is based on a single male specimen, collected far back in 1985 . The reality is that till now it remained unnoticed in the very large collection of Tenthredo pompilina Malaise. Earlier workers considered it as the population variation of Tenthredo pompilina Malaise and never paid special attention towards its independent specific identity. Before compiling this work the pompilina-complex was viewed very minutely and it had broken into a group of very distinct species having altogether different genitalic specifications.

This new species is closely related to Tenthredo breviantennata sp. nov. on the basis of subapical tooth of tarsal claw distinctly longer than apical one, but can be set aside from that as follows. Tenthredo fuscoventris has abdomen entirely fuscous; antenna long, equiform and 3x head width; clypeus subrectangularly incised; median fovea broad, canaliculate and shallowly reaching median ocellus; frontal ridges broad and with dense, large, confluenting punctures, whereas in Tenthredo breviantennata the features are: abdomen black with anterior half of tergite four pale; antenna comparatively short, some apical segments compressed, $2.4 \mathrm{x}$ head width; clypeus circularly incised; median fovea deep, ditch-like and clearly reaching median ocellus; frontal ridges narrow and with dense, minute, distinct punctures.

\section{Female}

Yet to be discovered.

\section{Male}

Colour: Body fuscous to black, pale whitish are: clypeus, labrum, mandible barring apex, deltoid spot on lower hind orbit touching eye; posterodorsal and anterolateral margin of pronotum, ridges lateral to scutelli, deflexed lateral sides of tergites two to four and corresponding sternites entirely; anterior aspect of proleg, anterior aspect of coxa and apical half of mesofemur, deltoid spot on inner anterolateral aspect of metacoxa. Wings hyaline with infumated crossband over stigma on forewing, venation including costa, subcosta and stigma fuscous.

Structure: Length $8 \mathrm{~mm}$. Antenna filiform, 3x head width, flagellum with apical four segments faintly compressed; scape and pedicel as $4: 3$, segment three slightly longer than four; clypeus (Fig. 7) subrectangularly incised up to half of its length with rounded lateral teeth; labrum (Fig. 7) broader than long as $4: 3$ with roundly pointed anterior margin; malar space $0.3 \mathrm{x}$ diameter of median ocellus; LID:IDMO:EL=1.0:2.0:2.0; POL:OCL:OOL = 1.0:1.25:1.75; frontal area below level of eyes; median fovea (Fig. 9) broadly canaliculated, shallowly reaching median ocellus, and laterally limited by moderate supraantennal tubercles confluenting with low lying broad frontal ridges; postand interocellar furrows distinct, circumocellar furrows absent; lateral furrows distinct, diverging posteriorly; postocellar area subconvex, wider than long as $4: 3$; head narrowing behind eyes; ICD:ITD=1.0:3.5, mesoscutellum subconvexly round, its appendage carinate; mesepisternum obtusely round, mesosternum lacking thorns; metafemur equal to metatibia, metabasitarsus shorter than following three joints combined as 8:9; tarsal claw (Fig. 8) with subapical tooth almost equal to but stronger than apical one; IATS:MB:OATS $=1.0: 1.8: 0.7$.

Genitalia: Penis valve (Fig. 10), gonoforceps (Fig. 11).

Sculpture: Head shining with minute, shallow, confluenting punctures, more prominent, deep, dense, large and confluenting on frontal area; mesonotum with dense, minute, shallow, distinct punctures; mesoscutellum with dense, large, deep, distinct punctures, its appendage faintly wrinkled; mesepisternum rugose with dense, minute, confluenting punctures, more prominent on and along its convexity; mesosternum densely punctulate; abdomen faintly microstriated and with scattered, shallow punctures, surface subshining.
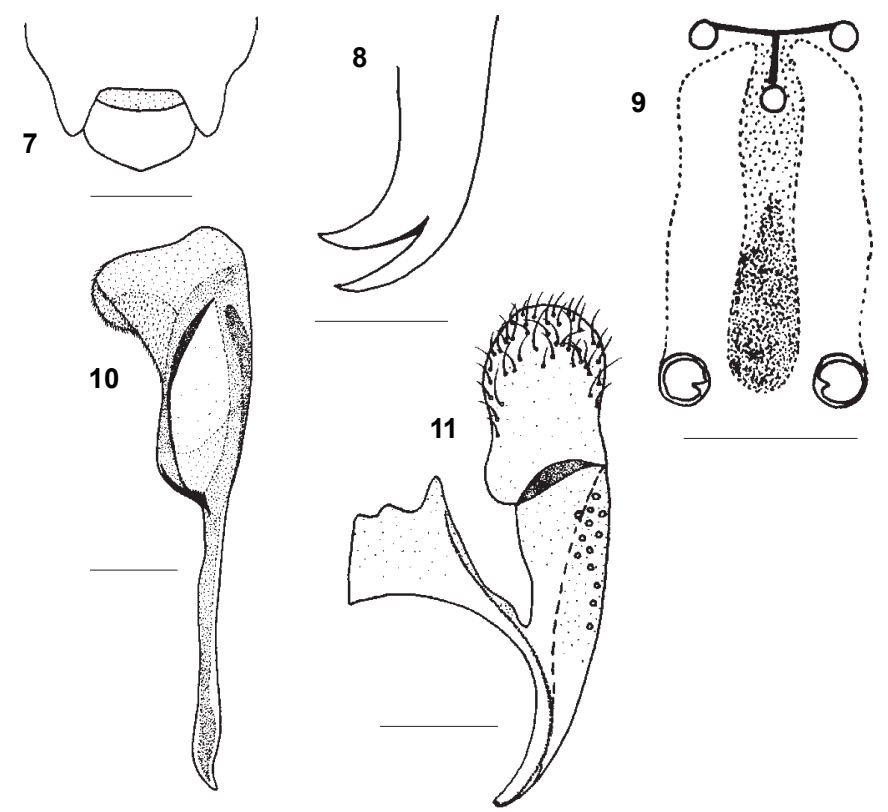

Figures 7-11. Tenthredo fuscoventris sp. nov. 7 - Clypeus and labrum; 8 - Tarsal claw; 9 - Median fovea (front view); 10 - Penis valve; 11 - Gonoforceps. Scale $=1.0 \mathrm{~mm}$ 
Pubescence: Silvery, $0.2 x$ scape length.

The type locality of this species is highly disturbed due to the fact that it is situated along a road connecting Gobindghat with Gangria and is always busy due to the pilgrimages visiting Hemkunt Sahib. For further collection of this species gorges along Badrinath road can be surveyed.

\section{Tenthredo breviantennata sp. nov.}

(Figs. 12-15)

\begin{abstract}
Material examined
Holotype: Female, Chakori, Uttar Pradesh, 2400m, 23.vi.1991, coll. V. Vasu.

Paratypes: 16 Females, four males, 22.vii.1982, Kalatop, Himachal Pradesh, 2400m, coll. M.S. Saini; three females, 11.vii.1991, coll. A. Singh; two females, 26.vi.1994, Kufri, 2400m, coll. M.S. Saini; four females, 23.vi.1985, Gobindghat, Uttaranchal, 2000m, coll. M.S. Saini; two females, two males, 20.vi.1991, Mukteshwer, 2700m, coll. D. Singh; four females, one male, 22.vi.1991, Pangot, 2400m, coll. V. Vasu; seven females, one male, 22.vi.1991, Binayak, 2300m, coll. M.S. Saini; eight females, 23.vi.1991, Chakori, 2400m, coll. V. Vasu; one female, 26.vi.1991, Kalamunitop, 2700m, coll. D. Singh; four females, one male, 28.vi.1991, Kilbury, 2400m, coll. A. Singh; one female, one male, 25.vi.1995, coll. M.S. Saini; four females, 26.vii.1992, Mandal, 2300m, coll. M.S. Saini; two females, 18.vi.1995, Gwaldam, 2000m, coll. V. Vasu; five females, one male, 30.iv.1986, Darjeeling, West Bengal, 2250m, coll. M.S. Saini; one female, one male, 18.ix.1992, Zunheboto, Nagaland, 1800m, coll. V. Vasu.
\end{abstract}

Individual variation: All specimens alike.

\section{Distribution}

India: Himachal Pradesh, Uttaranchal, West Bengal, Nagaland.

\section{Etymology}

Species name pertains to short antenna.

\section{Diagnostic features}

Tenthredo breviantennata sp. nov. is close to and comparable with Tenthredo fuscoventris sp. nov., but the two can be differentiated from each other on the basis of some characters already discussed under the latter.

\section{Female}

Colour: Body black, pale whitish are: clypeus except base, labrum except extreme margins, mandible barring apex, triangular spot on lower hind orbit; posterodorsal, ventral and posterolateral margins of pronotum, inner and outer margin of tegula, ridges lateral to meso- and metascutelli, outer margins of mesoscutellar appendage, spot behind metascutellum, narrow posterior and broad lateral margins of propodeum, anterior $1 / 3$ of tergites four in middle broadening towards lateral sides, sternite four; procoxa except base, anterior stripe on rest of proleg; apex of mesocoxa, anterior stripe on apical half of mesofemur, anterior deltoid spot on apex of mesotibia. Wings hyaline with distinct infuscated crossband over stigma on forewing, venation

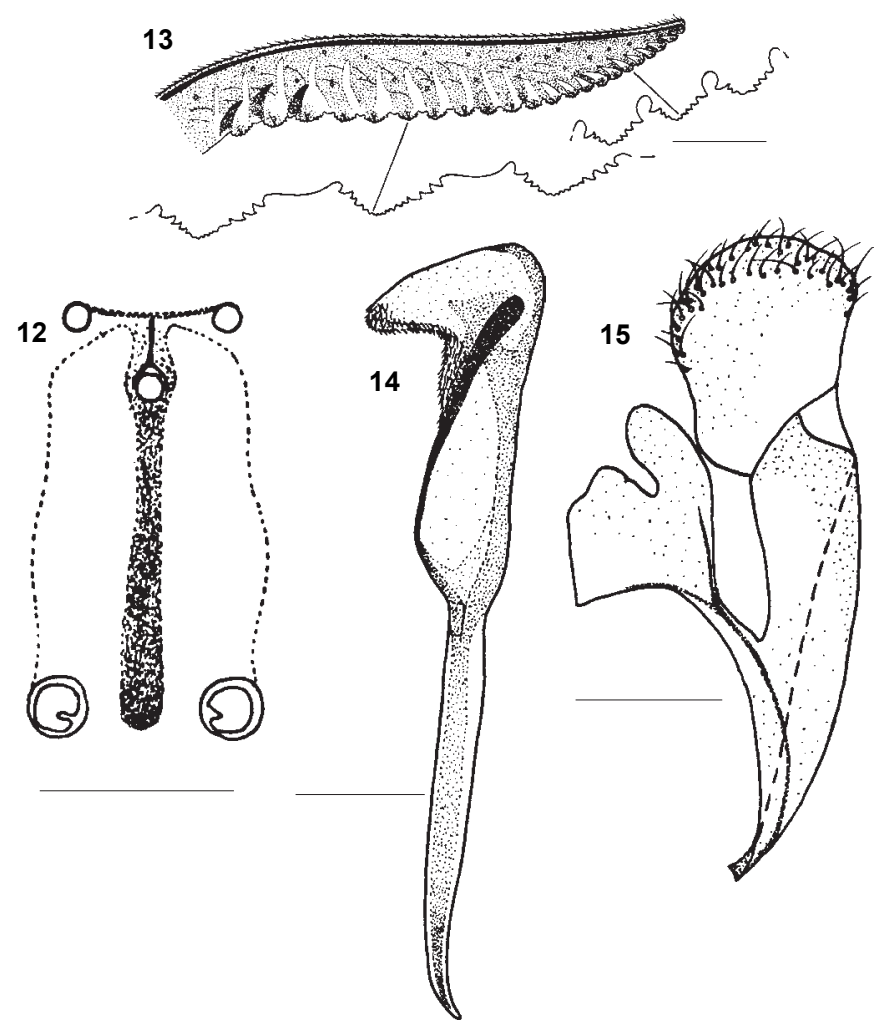

Figs. 12-15. Tenthredo breviantennata sp. nov. 12 - Median fovea (lateral view); 13 - Lancet; 14 - Penis valve; 15 - Gonoforceps. Scale $=1.0 \mathrm{~mm}$

including costa, subcosta and stigma fuscous.

Structure: Average length 9.0mm. Antenna filiform, 2.4x head width, flagellum with apical five segments compressed; scape and pedicel as 4:3, segment three slightly longer than four; clypeus circularly incised up to $1.2 \mathrm{x}$ its length; labrum wider than long as 4:3 with rounded anterior margin; malar space $0.3 \mathrm{x}$ diameter of median ocellus; LID:IDMO:EL =1.0:2.0:1.8, POL:OCL:OOL=1.0:1.5:1.75; frontal area at level of eyes; median fovea (Fig. 12) deep, ditch-like, clearly reaching median ocellus and laterally limited by moderately raised supraantennal tubercles confluenting with similarly raised narrow frontal ridges; postocellar furrow shallow, inter- and circumocellar furrows distinct; lateral furrows distinct, parallel; postocellar area wider than long as $4: 3$; head narrowing behind eyes; ICD:ITD = 1.0:3.0; mesoscutellum subconvexly round, its appendage carinate; mesepisternum obtusely round, mesosternum lacking thorns; metafemur longer than metatibia, metabasitarsus equal to following three joints combined; tarsal claw with subapical tooth equal to but stronger than apical one; IATS:MB:OATS = 1:1.5:1.75. Lancet (Fig. 13) with 22 serrulae.

Sculpture: Head shining, with dense, fine, shallow punctures, more prominent and distinct on frontal area; mesonotum with dense, minute, shallow punctures; mesoscutellum with large, deep, distinct punctures on posterior half, its appendage minutely wrinkled; mesepisternum with dense, fine, confluenting 
punctures, subrugose and prominent on its convexity; mesosternum densely punctulate; abdomen except polished propodeum and tergites 2-3, faintly microstriated with scattered, fine punctures, surface subshining.

Pubescence: Silvery, 0.2x scape length.

\section{Male}

Average length $7.0 \mathrm{~mm}$. Similar to female except whitish in addition are: coxae, trochanter and femur of mesoleg; dorsal aspect of metafemur, broad oval spot on anteroventral aspect of pronotum. Genitalia: Penis valve (Fig. 14), gonoforceps (Fig. $15)$.

\section{Remarks}

This is widely distributed species extending from extreme northwestern to extreme northeastern Himalaya in India. It was also kept under Tenthredo pompilina Malaise as its population variation. In distribution, behaviour and interaction with the surrounding ecological variants it resembles Tenthredo pompilina Malaise. It is all possible that in a single sweep both the species may be captured. Due to its large scale availability it can be easily traped with Malaise's trap. Its host plant remains unknown but its adults are generally found sitting and hovering around ferns growing mainly along the road sides.

\section{Tenthredo dif sp. nov.}

(Figs. 16-21)

\section{Material examined \\ Holotype: Female, 26.vi.1991, Kalamunitop, Uttar Pradesh, 2700m, coll. M.S. Saini. \\ Paratypes: One male, 26.vi.1991, Kalamunitop, Uttar Pradesh, 2700m, coll. V. Vasu; one female, 5.vi.1983, Hanuman Chatti, Uttaranchal, 2000m, coll. M.S. Saini; one male, 22.vi.1991, Binayak, 2300m, coll. V. Vasu; two females, 23.vii.1982, Kalatop, Himachal Pradesh, 2400m, coll. M.S. Saini; one male, 30.iv.1986, Darjeeling, West Bengal, 2250m, coll. M.S. Saini.}

Individual variation: Anterior margin of tergite three pale whitish.

\section{Distribution}

India: Himachal Pradesh, Uttaranchal, West Bengal.

\section{Etymology}

Species name is derived from an arbitrary combination of letters taken from distinct interocellar furrow.

\section{Diagnostic features}

Tenthredo dif sp. nov. with abdomen coal black is distinct from Tenthredo fuscoventris sp. nov. and Tenthredo breviantennata sp. nov. on the basis of subapical tooth of claw shorter than apical one. However, it shares this character with Tenthredo dalhousiensis Singh et al., Tenthredo santokhi Singh \& Saini, Tenthredo serraflata Singh et al. and Tenthredo ifa sp. nov., but the comparative length of antennal segments three and four breaks this group of five species into two further subgroups of three and two species. Tenthredo ifa and the species under discussion fall into a group with antennal segment three at most equal to four, whereas in the group of remaining three species antennal segment three distinctly longer than four. Tenthredo dif and Tenthredo ifa can be distinguished as: mesoscutellum impunctate, postocellar area wider than long as $2: 1$; antenna short, $2.3 \mathrm{x}$ head width, and mesopleura not rugose in Tenthredo dif, whereas in Tenthredo ifa mesoscutellum distinctly punctate, postocellar area wider than long as $3: 2$; antenna long, $3 \mathrm{x}$ head width, and mesopleura rugose with dense, large, confluenting punctures.

\section{Female}

Colour: Body black, pale whitish are: clypeus except margins and medial narrow band, labrum except margins, mandible barring apex, triangular spot on lower hind orbit touching eye; posterodorsal, ventral and anterolateral margins of pronotum, inner and outer margins of tegula, ridges lateral to scutelli, spot behind metascutellum, extreme posterior and narrow lateral margins of propodeum, deflexed lateral sides of tergites four and corresponding sternite, tergite nine except triangular anterolateral sides; anterior aspect of proleg except extreme base of coxa, apex of mesocoxa, anterior aspect of apical half of mesofemur, extreme apex of metacoxa. Wings hyaline with infuscated crossband over stigma in forewing; venation including costa, subcosta and stigma fuscous.

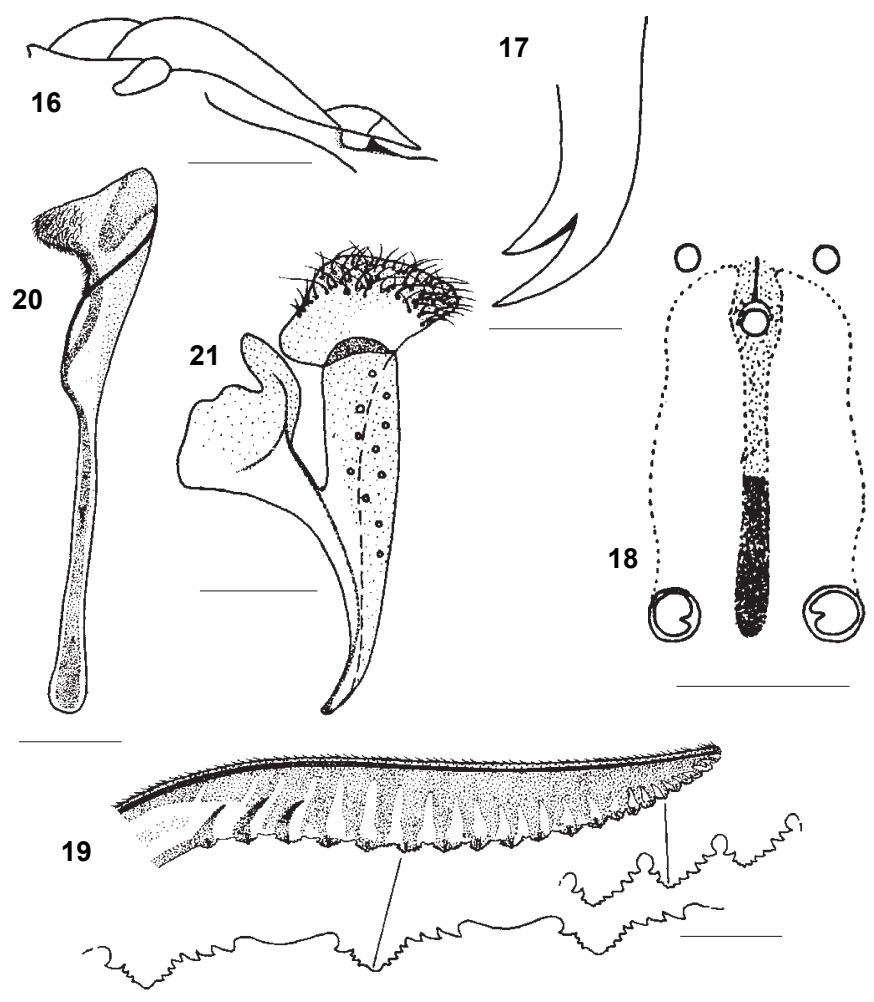

Figs. 16-21. Tenthredo dif sp. nov.

16 - Lateral view of thorax (dorsal view); 17 - Tarsal claw;

18 - Median fovea (lateral view); 19 - Lancet; 20 - Penis valve; 21 - Gonoforceps. Scale $=1.0 \mathrm{~mm}$ 
Structure: Average length $7.0 \mathrm{~mm}$. Antenna $2.3 \mathrm{x}$ head width, flagellum with apical four segments insignificantly compressed; scape and pedicel as 4.0:3.0, segment three slightly shorther than four; clypeus semicircularly incised up to $1 / 3$ of its length with rounded lateral teeth, labrum broader than long as 3:2 with rounded anterior margin; malar space $0.6 \mathrm{x}$ diameter of median ocellus; LID:IDMO:EL = 1.0:1.75:1.5, POL:OCL:OOL = 1.0:0.75:2.0; frontal area below level of eyes, median fovea (Fig. 18) deep, ditch-like in anterior half and shallowly reaching median ocellus, and laterally limited by slightly indicated supraantennal tubercles confluenting with similar frontal ridges; postocellar furrow absent, interocellar furrow distinct, circumocellar furrows shallow; lateral furrows sunken, bulging medially; postocellar area subconvex, wider than long as $2: 1$; head narrowing behind eyes; ICD:ITD = 1.0:3.0; mesoscutellum pulvinate (Fig. 16), its appendage faintly carinate; mesepisternum obtusely round, mesosternum lacking thorns; metafemur longer than metatibia, metabasitarsus equal to following three joints combined; tarsal claw (Fig. 17) with subapical tooth shorter than apical one; IATS:MB:OATS = 1.0:1.5:0.9. Lancet (Fig. 19) having 21 serrulae.

Sculpture: Head shining with dense, fine, shallow punctures; mesonotum with dense, fine, deep punctures, surface shining; mesoscutellum and its appendage impunctate; mesopleuron with dense, minute, distinct punctures, more prominent on lower half of convexity, surface shining; mesosternum punctate like mesonotum; abdomen faintly microstriated with scattered, fine punctures, surface subshining.

Pubescence: Silvery, $0.15 \mathrm{x}$ scape length.

\section{Male}

Average length $6.0 \mathrm{~mm}$. Similar to female except, pale whitish in addition are: clypeus and labrum entirely, anterior aspect of coxa, trochanter and femur of mesoleg, dorsal stripe on metafemur, anterior half of tergite four, sternites two to five entirely. Genitalia: Penis valve (Fig. 20), gonoforceps (Fig. 21).

\section{Remarks}

It is a widely distributed right from northwest to northeastern Himalaya in India and remains active during premonsoon to postmonsoon season. From its long flight period it seems to be bivoltine.

\section{Tenthredo ifa sp. nov.} (Figs. 22-24)

\section{Material examined}

Holotype: Female, 17.vi.1995, Gwaldam, Uttaranchal, 2000m, coll. M.S. Saini.

\section{Etymology}

Species name is an arbitrary combination of letters, taken from interocellar furrows absent.

\section{Diagnostic features}

Tenthredo ifa sp. nov. is closely related to Tenthredo dif sp. nov. but they can be easily separated from each another on the basis of some distinct characters already discussed under the latter.

Represented by a single female specimen Tenthredo ifa belongs to such a remote and undeveloped area of Uttaranchal, that faces the agony of devastating forest fire almost every year during the premonsoon months. The insect population comes to its lowest ebb and it takes a lot of time for every species to regenerate, raise and establish its population once again. It is on this account that species diversity is much more as compare to species population. Many new species from this area have been collected but almost all of them are represented by a very small number of specimens. There is almost no trend of reforestations and the local people do not care of the reserve forests and the grazing cattles (cows, sheeps and goats) roam about freely. Every fresh seedling or freshly planted tree, if any, is destroyed in such instances.

\section{Female}

Colour: Body black, pale whitish are: clypeus, labrum, mandible barring apex, triangular spot on lower hind orbit; posterodorsal, posterolateral and ventral margins of pronotum, tegula, ridges lateral to scutelli, outer margins of mesoscutellar appendage, spot behind metascutellum, narrow posterior and broad lateral margins of propodeum, deflexed lateral sides of all tergites, posterior margins of all sternites; front four legs except posterior stripe on tibiae and tarsi, apex of metacoxa, metafemur except apical ring. Wings hyaline with infuscated crossband over stigma on forewing; venation including costa, subcosta and stigma fuscous to black.

Structure: Length $8.0 \mathrm{~mm}$. Antenna $2.2 \mathrm{x}$ head width, flagellum with apical five segments compressed; scape and pedicel as 5.0:3.0, segments three and four almost equal; clypeus (Fig. 22) arcuately incised up to $1 / 3$ of its length with truncate lateral teeth, labrum (Fig. 22) broader than long as 5:4 with roundly pointed anterior margin; malar space $0.75 \mathrm{x}$ diameter of median ocellus; LID:IDMO:EL = 1.0:1.8:1.5, POL:OCL:OOL = 1.0:1.5:1.5; frontal area below level of eyes; median fovea deeply canaliculate and limited by moderately raised supraantennal tubercles confluenting with similar frontal ridges; post- and interocellar furrows absent, circumocellar furrows distinct; lateral furrows distinct, parallel; postocellar area wider than long as $3: 2$; head narrowing behind eyes; ICD:ITD=1.0:3.5; mesoscutellum subconvexly roundly pointed (Fig. 23), its appendage carinate; mesepisternum obtusely round, mesosternum lacking thorns; metafemur longer than metatibia, metabasitarsus equal to following three joints combined; tarsal claw with subapical tooth shorter than apical one; IATS:MB:OATS = 1:1.6:0.7. Lancet (Fig. 24) having 20 serrulae.

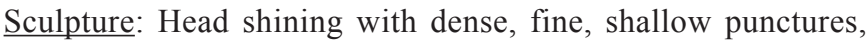
more prominent and somewhat confluenting on frontal ridges; mesonotum shining with dense, minute, distinct punctures; mesoscutellum with large, scattered, deep punctures on posterior slope, its appendage wrinkled; mesepisternum rugose with dense, large, confluenting punctures; mesosternum, densely punctulate; abdomen faintly microstriated with dense, 


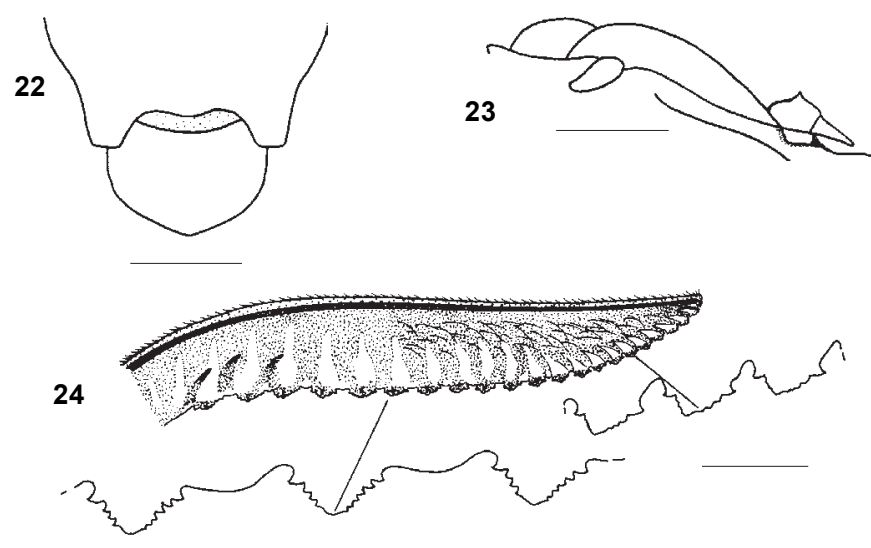

Figs. 22-24. Tenthredo ifa sp. nov.

22 - Clypeus and labrum; 23 - Lateral view of thorax (dorsal view); 24 - Lancet. Scale $=1.0 \mathrm{~mm}$

minute, shallow punctures, surface subshining.

Pubescence: Mixed fuscous and silvery, $0.2 x$ scape length.

Male

Yet to be discovered.

\section{Remarks}

From the geographical point of view though this area is cut off from the surrounding hills yet ecologically it is much similar to Pathoragarh, Rampur, Kumaun and Joshimath. We hope to get more specimens of this species including its males if the above mentioned areas are thoroughly surveyed.

\section{Tenthredo dalhousiensis Singh et al. ${ }^{\text {w }}$ (Images 10-13 ${ }^{\mathrm{w}}$ )}

${ }^{\mathrm{w}}$ Text and Images in the web supplement at www.zoosprint.org

\section{Tenthredo santokhi Singh \& Saini ${ }^{\mathrm{w}}$}

(Images 14-16 ${ }^{\mathrm{w}}$ )

${ }^{\mathrm{w}}$ Text and Images in the web supplement at www.zoosprint.org

\section{Tenthredo serraflata Singh et al. ${ }^{\text {w }}$ (Images 17-20w)}

${ }^{\mathrm{w}}$ Text and Images in the web supplement at www.zoosprint.org

\section{Tenthredo foveolata sp. nov.}

(Figs. 25-27)

\section{Material examined \\ Holotype: Female, 28.vi.1991, Kilbury, Uttaranchal, 2400m, coll. M.S. Saini. \\ Paratype: Male, 26.vi.1991, Kalamunitop, Uttaranchal, 2600m,} coll. M.S. Saini.

\section{Etymology}

Species names pertains to ditch-like median fovea.

\section{Diagnostic features}

With coal black abdomen, subapical tooth of tarsal claw equal to apical one and antennal segment three distinctly longer than four, Tenthredo foveolata sp. nov. and Tenthredo fusutibiae sp. nov. gets separated from rest of the species of the pompilina-complex. However, to segregate these two species from each other, the following characters are helpful. In Tenthredo foveolata all tibiae and tarsi black, mesopleura is entirely rugose, median fovea ditch-like and clearly reaching median ocellus, antennal segment three and four as 4:3, and scape and pedicel as 4:3. However, in Tenthredo fusutibiae all tibiae and tarsi fuscous; ventral half of mesopleura rugose whereas posterior half with large and scattered punctures having smaller ones on the intervening spaces, median fovea though ditch-like yet only broadly and shallowly reaching median ocellus, antennal segment three and four as $3: 2$, and scape and pedicel as 2:1.

\section{Female}

Colour: Body black, pale whitish are: medial horizontal band on clypeus, basal spot on labrum, mandible barring apex; posterodorsal margin of pronotum, basal and inner apical spots on tegula, ridges lateral to scutelli; narrow lateral margins of propodeum, deflexed lateral sides of tergite four triangularly indicated above on anterolateral aspect, sternite four; anterior aspect of profemur except basal 1/4 onwards, anterior aspect of apical half of mesofemur. Wings hyaline with infuscated crossband over stigma on forewing, venation including costa, subcosta and stigma fuscous to black.

Structure: Length $8.0 \mathrm{~mm}$. Antenna incrassate before apex, $2.2 \mathrm{x}$ head width, flagellum not compressed, scape and pedicel as 4.0:3.0, segments three and four as 4:3, clypeus subrectangularly incised upto $1 / 3$ of its length with rounded lateral teeth, labrum broader than long as 5:3 with rounded anterior margin; malar space $1.0 \mathrm{x}$ diameter of median ocellus; LID:IDMO:EL = 1.0:1.8:1.5, POL:OCL:OOL = 1.0:1.4:2.0; frontal area below level of eyes; median fovea broad, ditch-like and clearly reaching median ocellus, and laterally limited by moderately raised supraantennal tubercles confluenting with similar frontal ridges; postocellar furrow absent, inter- and circumocellar furrows distinct; lateral furrows distinct, parallel; postocellar area convex, wider than long as 2:1, with median longitudinal and transverse hind carinae; head narrowing behind eyes; ICD:ITD $=1.0: 3.0$, mesoscutellum subconvex, its appendage carinate; mesepisternum obtusely round, mesosternum without thorns; metafemur equal to metatibia, metabasitarsus equal to following three joints combined; tarsal claw with subapical tooth almost equal to apical one; IATS:MB:OATS $=1: 1.8: 0.75$. Lancet (Fig. 25) having 23 serrulae.

Sculpture: Head shining with dense, minute, distinct, shallow punctures, more prominent on frontal ridges; mesonotum punctate like frontal ridges; mesoscutellum with large, scattered, deep punctures on posterior slope, its appendage wrinkled; mesepisternum rugose with dense, large, deep, confluenting punctures; mesosternum densely punctate; abdomen shining with faint microstriations and inconspicuous punctures. 


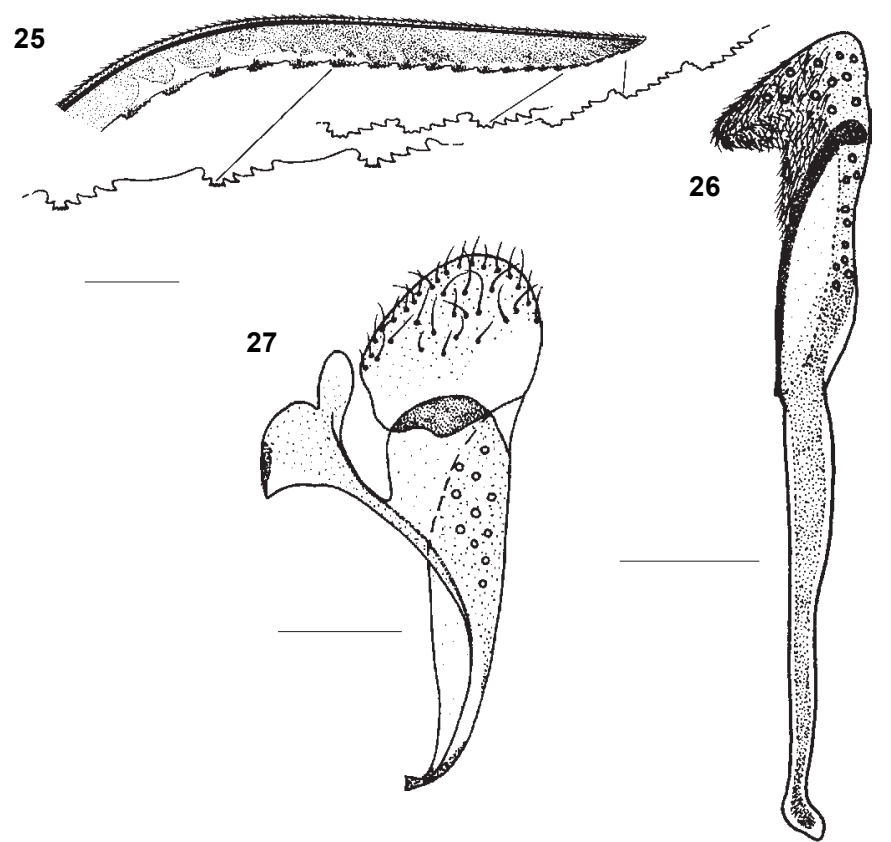

Figs. 25-27. Tenthredo foveolata sp. nov. 25 - Lancet; 26 - Penis valve; 27 - Gonoforceps. Scale = 1.0mm

Pubescence: Silvery, $0.15 x$ scape length.

\section{Male}

Length $7.0 \mathrm{~mm}$. Similar to female except clypeus and labrum entirely whitish, lateral spot on tergite four broadly confluenting above. Genitalia: Penis valve (Fig. 26), gonoforceps (Fig. 27).

\section{Remarks}

This small sized species is confined to the upper ranges of Kumaun Hills of Uttaranchal. Both of its collection localities are quite undisturbed and humid places with a very rich growth of the shrubs. It rains heavily even during premonsoon period in these areas. Though presently under the stress of grazing, yet these are lush green spots of Uttaranchal. These should be declared as reserved santuaries so as to preserve representative fauna and flora of the state.

From an over all appearance and behaviour this species is closely related to so many other species of this group. So in the field its specific collection cannot be made. Areas below Ranikhet, Mukteshwer and Gwaldam can be explored from its angle.

\section{Tenthredo fuscitibiae sp. nov.}

(Figs. 28-29)

\section{Material examined}

Holotype: Female, 20.vii.1994, Flower Valley, Uttaranchal, 3200m, coll. V. Vasu.

\section{Etymology}

Species name is after fuscous tibiae.

\section{Diagnostic features}

Tenthredo fuscitibiae sp. nov. is closely allied to Tenthredo foveolata sp. nov. but the two can be set aside on the basis of a set of characters already discussed under the latter. Some of its specific characters which can be further helpful to keep it apart from rest of the Oriental species of the genus Tenthredo Linnaeus include: its very small sized body $(6.0 \mathrm{~mm})$ as compared to the other species of this group, and also pale whitish lateral spots on the clypeus, clypeus rectangularly incised upto $1 / 3$ of its length, mesoscutellum subconvex with longitudinal carination on its posterior slope, and densely punctate mesosternum.

\section{Female}

Colour: Body black, pale whitish are: lateral spots on clypeus, basal spot on labrum, mandible barring apex; posterodorsal, posterolateral and ventral margins of pronotum, inner and outer margins of tegula, ridges lateral to meso- and metascutelli; lateral margins of propodeum, deflexed lateral sides of tergite four more or less, spot on tergite nine, sternite four more or less; anterior aspect of proleg except base of coxa; apical half of mesofemur anteriorly; mesotibia and tarsi anteriorly; anterior aspects of metatarsi. Wings hyaline with infuscated band over stigma on forewing, venation including costa, subcosta and stigma fuscous.

Structure: Length $6.0 \mathrm{~mm}$. Antenna incrassate before apex, 1.9x head width, flagellum not compressed, scape and pedicel as $2.0: 1.0$, segments three and four as $3: 2$; clypeus rectangularly incised up to $1 / 3$ of its median length with rounded lateral teeth; labrum broader than long as 5:3 with roundly pointed anterior margin; malar space $0.6 x$ diameter of median ocellus; LID:IDMO: $\mathrm{EL}=1.0: 1.9: 1.5, \mathrm{POL}: \mathrm{OCL}: \mathrm{OOL}=1: 0.8: 1.5$; frontal area below level of eyes; median fovea (Fig. 28) narrow ditch-like and broadly but shallowly reaching median ocellus, and laterally limited by moderately raised supraantennal tubercles confluenting with low lying frontal ridges; postocellar furrow absent; inter- and circumocellar furrows distinct, lateral furrows distinct, parallel; postocellar area convex, wider than long as 2:1 with median longitudinal and transverse hind carinae; head narrowing behind eyes; ICD:ITD = 1.0:2.5, mesoscutellum subconvex, carinate on posterior slope, its appendage carinate; mesepisternum obtusely round, mesosternum lacking thorns; metafemur equal to metatibia, metabasitarsus equal to following three joints combined; tarsal claw with subapical tooth almost equal to apical one; IATS:MB:OATS = 1.0:1.6:0.9. Lancet (Fig. 29) having 21 serrulae.

Sculpture: Head shining with dense, fine, distinct punctures; mesonotum shining with dense, minute, shallow punctures, mesoscutellum with scattered, distinct punctures on posterior half only, its appendage wrinkled; mesepisternum with dense, minute, distinct punctures, but prominent, confluenting and intermingled with large, deep ones on lower half of convexity; mesosternum densely punctulate; abdomen subshining, faintly microstriated.

Pubescence: Silvery, $0.15 x$ scape length. 


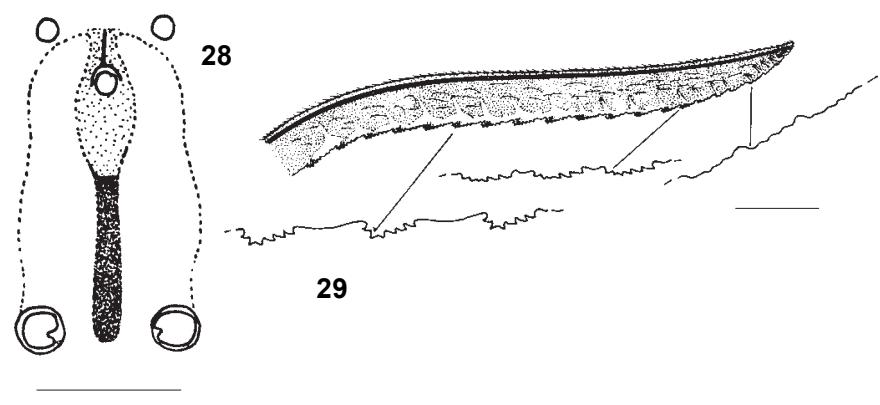

Figs. 28-29. Tenthredo fuscitibiae sp. nov. 28 - Median fovea (front view); 29 - Lancet. Scale $=1.0 \mathrm{~mm}$

Male

Yet to be discovered.

\section{Remarks}

Due to a tourist spot its type locality is quite disturbed. Though declared as reserve sanctuary, yet tourists freely roam about in this area after completing a formality of gate passes. As compared to 1980's the sawfly fauna of this area has alarmingly declined. Species diversity may be the same but their populations are extremely low. Now with the construction of a new approach road, this area will get further disturbed and polluted due to vehicular exhausts. Government should take some strict measures to protect and conserve this area. For further collection of this species ecologically similar areas i.e. Chopta, Gwaldam and Kalamunitop can be surveyed.

\section{Tenthredo pompilina Malaise $\mathrm{w}^{\mathrm{w}}$ \\ (Images 21-24w)}

${ }^{w}$ Text and Images in the web supplement at www.zoosprint.org

\section{Tenthredo brevitarsus sp. nov.}

(Figs. 30-32)

\section{Material examined}

Holotype: Female, 25.vii.1982, Himachal Pradesh, Kalatop, 2400m, coll. M.S. Saini.

Paratypes: Two females, one male, female, 25.vii.1982, Himachal Pradesh, Kalatop, 2400m, coll. M.S. Saini; one female, one male, 19.vi.1991, Ramgarh, Uttaranchal, 2000m, coll. V. Vasu; two females, one male, 23.vi.1991, Chakori, 2400m, coll. V. Vasu; one female, 26.vi.1991, Kalamunitop, 2700m, coll. M.S. Saini; two females, 28.vi.1991, Kilbury, 2400m, coll. V. Vasu; two females, 28.vi.1991, Kunjkharag, 2600m, coll. V. Vasu. one female, 30.iv.1986, Darjeeling, West Bengal, 2250m, coll. M.S. Saini.

Individual variations: All specimens alike.

\section{Distribution}

India: Uttaranchal, Himachal Pradesh, West Bengal.

\section{Etymology}

Metabasitarsus shorter than following three joints combined forms the basis of species name.

\section{Diagnostic features}

Tenthredo brevitarsus is closely allied to Tenthredo equitarsus on the basis of presence of circumocellar furrows, a common character between the two. However, both are quite distinct from one another and the following combination of characters segregates the two: metabasitarsus shorter than following three joints combined, clypeus whitish yellow entirely, and postocellar area wider than long as 7:4 in T. brevitarsus whereas, in Tenthredo equitarsus postocellar area wider than long as $3: 2$, metabasitarsus almost equal to following three joints combined, clypeus black towards base.

\section{Female}

Colour: Body black, pale whitish are: clypeus and labrum except margins, mandible barring apex, posterodorsal margin of pronotum, inner and outer margins of tegula, ridges lateral to scutelli, spot behind metascutellum; posterior and lateral margins of propodeum, lateral sides of tergite four and corresponding sternite; anterior aspect of proleg except from coxa to basal $1 / 4$ of femur, anterior spots on apices of femur and tibia of mesoleg. Wings hyaline with infuscated crossband over stigma on forewing, venation including costa, subcosta and stigma fuscous.

Structure: Average length $8.5 \mathrm{~mm}$. Antenna filiform, 2.8x head width, flagellum with apical five segments insignificantly compressed, scape and pedicel as 5:3, segments three and four almost equal; clypeus subrectangularly incised upto half of its length with rounded lateral teeth; labrum broader than long as $4: 3$ with rounded anterior margin; malar space $0.5 x$ diameter of median ocellus; LID:IDMO:EL = 1.0:1.5:1.5; POL:OCL:OOL = 1.0:1.2:1.8; frontal area below level of eyes; median fovea broad, ditch-like, reaching median ocellus, and laterally limited by moderately raised supraantennal tubercles confluenting with low lying frontal ridges; postocellar furrow absent, inter- and circumocellar furrows distinct; lateral furrows distinct, almost parallel; postocellar area convex, wider than long as 7:4, with transverse hind carina, head narrowing behind eyes; ICD:ITD = 1.0:3.0; mesoscutellum subconvex, its appendage carinate; mesepisternum obtusely round, mesosternum lacking thorns; metafemur longer than metatibia, metabasitarsus shorter than following three joints combined as $6: 7$; tarsal claw with subapical tooth equal to apical one; IATS:MB:OATS = 1.0:1.5:0.75. Lancet (Fig. 30) having 22 serrulae.

Sculpture: Head shining with dense, fine, distinct punctures; mesonotum shining with dense, minute, distinct punctures; mesoscutellum with large, scattered, deep punctures on posterior slope, its appendage wrinkled; mesopleura rugose with dense, large, deep confluenting punctures; mesosternum densely punctulate; abdomen subshining, faintly microstriated and with dense, fine punctures.

Pubescence: Silvery, $0.15 x$ scape length.

\section{Male}

Average length $7.5 \mathrm{~mm}$. Similar to female except pale whitish in addition are: clypeus and labrum entirely, anterior aspect of 


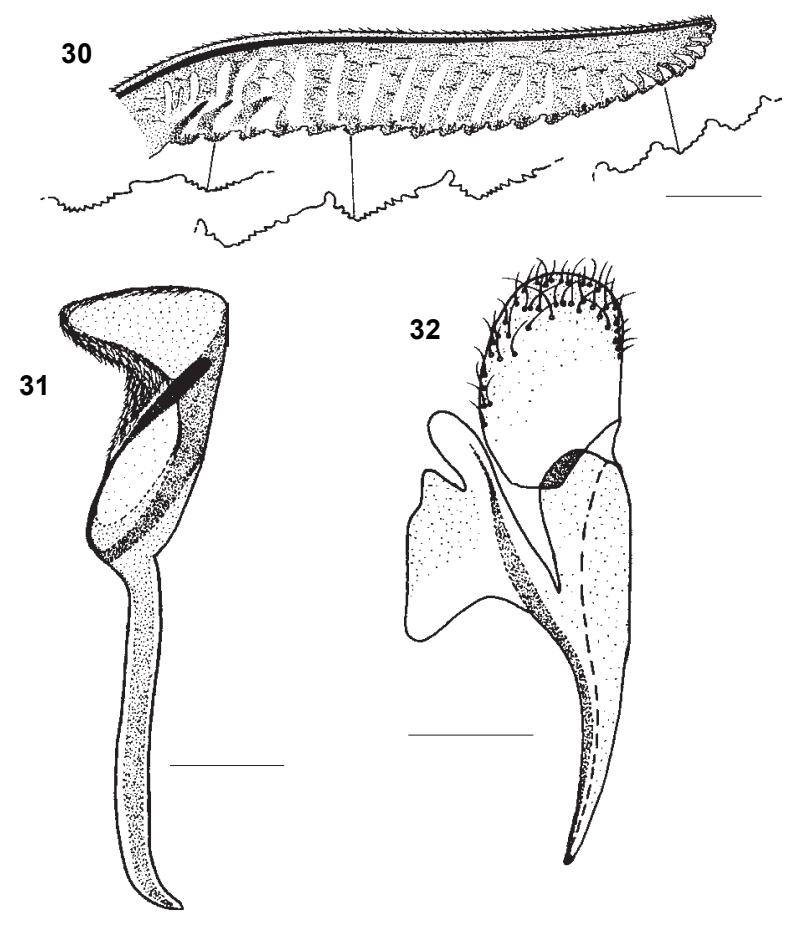

Figs. 30-32. Tenthredo brevitarsus sp. nov. 30 - Lancet; 31 - Penis valve; 32 - Gonoforceps. Scale $1.0 \mathrm{~mm}$

proleg entirely, lateral spots of tergite four confluenting above, deflexed lateral sides of tergites 2-5 more or less and corresponding sternites more or less. Genitalia: Penis valve (Fig. 31), gonoforceps (Fig. 32).

\section{Remarks}

This species is widely distributed almost throughout the himalayan belt and is adapted to almost all kinds abiotic factors. It is available during monsoon months also. In most of the habits it is very close to Tenthredo pompilina Malaise.

\section{Tenthredo equitarsus sp. nov.}

(Figs. 33-37)

\section{Material examined}

Holotype: Female, 28.vi.1991, Kilbury, Uttaranchal, 2400m, coll. M.S. Saini.

Paratypes: Three males with same data as holotype, two females, one male, 15.vi.1991, coll. V. Vasu. Chopta, Uttaranchal, 2700m, one male, 13.vi.1985, coll. M.S. Saini; Ramgarh, 1800m, one female, one male, 19.vi.1991, coll. M.S. Saini; Mukteshwer, 2700m, one female, 20.vi.1991, coll. A. Singh. Himachal Pradesh, Kalatop, 2400m, one male, 10.vii.1983, coll. M.S. Saini.

Individual variations: All specimens alike.

\section{Distribution}

India: Himachal Pradesh, Uttaranchal.

\section{Etymology}

Metabasitarsus equal to following three joints combined, form the basis of its name.

\section{Diagnostic features}

Tenthredo equitarsus is closely allied to Tenthredo brevitarsus but two can be separated on the basis of some key characters as discussed under the latter.

\section{Female}

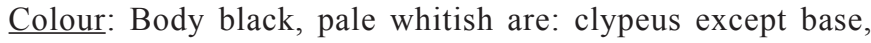
labrum except margins, mandible barring apex; posterodorsal margin of pronotum, inner and outer margin of tegula, ridges lateral to scutelli, spot behind metascutellum, dot on extreme lateral margin of propodeum, broad triangular spot on lateral sides of tergite four narrowly medially confluenting; anterior aspect of apical $3 / 4$ of femur to rest of parts of proleg, anterior deltoid spots on apices of femur and tibia of mesoleg. Wings hyaline with infuscated crossband over stigma on forewing, venation including costa, subcosta and stigma fuscous.

Structure: Average length $7.5 \mathrm{~mm}$. Antenna $2.5 \mathrm{x}$ head width, flagellum with apical four segments insignificantly compressed, scape and pedicel as 5.0:4.0, segments three and four almost equal; clypeus (Fig. 33) subrectangularly incised upto $1 / 3$ of its length with truncate lateral teeth, labrum (Fig. 33) broader than long as $4: 3$ with rounded anterior margin; malar space $0.5 \mathrm{x}$ diameter of median ocellus; LID:IDMO:EL $=1.0: 1.5: 1.5$, POL:OCL:OOL $=1.0: 1.5: 1.8$; frontal area below level of eyes, median fovea ditch-like, clearly reaching median ocellus with a blunt carina in anterior half, and laterally limited by moderately raised supraantennal tubercles confluenting with almost similar frontal ridges; postocellar furrow absent, inter- and circumocellar ones distinct; lateral furrows deep, slightly bulging medially; postocellar area convex, wider than long as 3:2, and with transverse hind carina; head narrowing behind eyes; ICD:ITD = 1.0:3.0, mesoscutellum subconvex, its appendage carinate, mesepisternum obtusely round, mesosternum lacking thorns; metafemur longer than metatibia, metabasitarsus almost equal to following three joints combined, tarsal claw (Fig. 34) with subapical tooth almost equal to apical one; IATS:MB:OATS = 1.0:1.6:0.8. Lancet (Fig. 35) having 22 serrulae.

Sculpture: Head shining with dense, fine shallow punctures, more prominent on frontal ridges; mesonotum punctate like frontal ridges; mesoscutellum with large, scattered punctures on posterior half, its appendage wrinkled; mesepisternum rugose with dense large, confluenting punctures, more distinct on lower half of convexity, mesosternum densely punctulate; abdomen except polished propodeum finely punctate with faint microstriations.

Pubescence: Silvery, $0.15 x$ scape length.

\section{Male}

Average length $7.0 \mathrm{~mm}$. Similar to female except whitish are: clypeus and labrum entirely; entire anterior aspect of proleg; mesocoxa and trochanter except fuscous medial spots, 

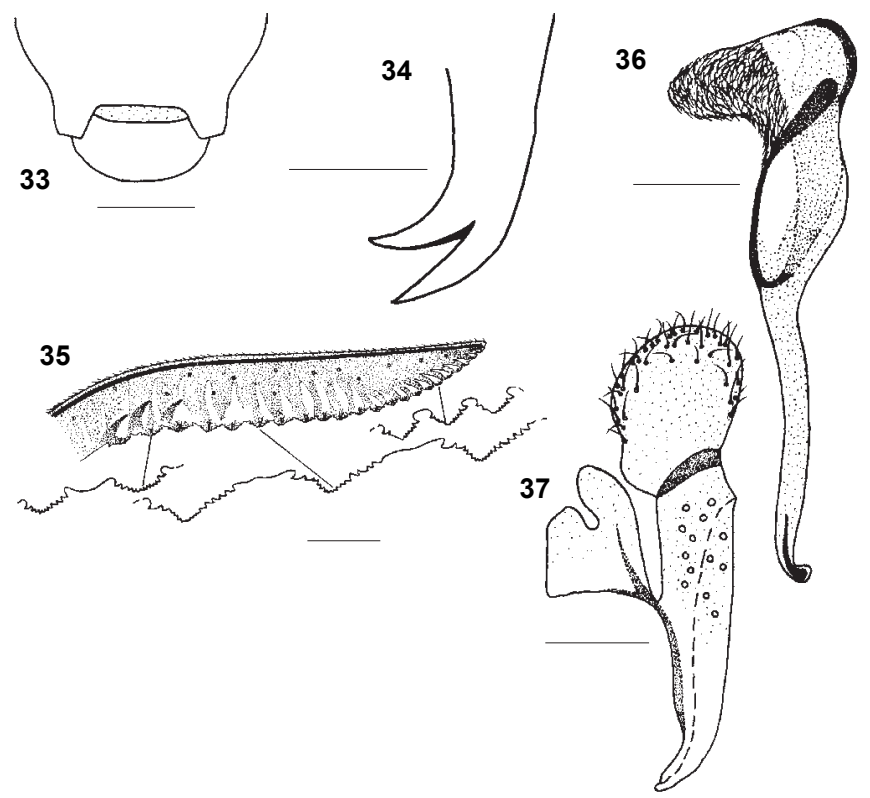

Figs. 33-37. Tenthredo equitarsus sp. nov. 33 - Clypeus and labrum; 34 - Tarsal claw; 35 - Lancet; 36 - Penis valve; 37 - Gonoforceps. Scale $=1.0 \mathrm{~mm}$

mesofemur posteriorly except basal $1 / 3$, dorsal stripe on metatibia; broad anterior margin of tergite four, deflexed lateral sides of tergites two to five and corresponding sternites. Genitalia: Penis valve (Fig. 36), gonoforceps (Fig. 37).

\section{Remarks}

Confined to the northwestern Himalayan ranges, this species occupies those ecological niches that are comparatively more humid. Unlike many other species of this group, this species did not bother about road side disturbance and pollution. It has predilection for all kinds of medium sized shrubs and is generally available in those areas where sawflies of subfamily, selandriinae are available. It has close association with the ferns and plants of Polygonum chinensis. Whether the latter is its host or not yet remains to be confirmed. This species can be better collected with Malaise traps rather than collection nets. Even with mild wind currents its activity comes to an end. Like Tenthredo pompilina Malaise it is very important and integral part of insect food chains. It is quite oftenly attacked by the same predators which attack Tenthredo pompilina Malaise. Its flight period extends over the monsoon months.

\section{Tenthredo picfa sp. nov.}

(Figs. 38-40)

\section{Material examined}

Holotype: Female, 21.v.1985, Flower Valley, Uttaranchal, 3200m, coll. M. S. Saini.

Paratypes: One female, 30.iv.1986, Darjeeling, West Bengal, 2280m, coll. D. Singh; one female, one male, 18.vii.1991, Kalatop, Himachal Pradesh, 2400m, coll. V. Vasu; one female, 22.iv.1992, Tawang, Arunachal Pradesh, 2000m, coll. M.S. Saini.
Individual variations: All specimens alike.

\section{Distribution}

India: Arunachal Pradesh, Himachal Pradesh, Uttaranchal, West Bengal.

\section{Etymology}

Species name is derived from an arbitrary combination of letters from post-, inter- and circumocellar furrows absent.

\section{Diagnostic features}

By having subapical tooth of tarsal claw equal to apical one, antennal segment three almost equal to four and circumocellar furrows being absent, Tenthredo picfa sp. nov. is closely allied to Tenthredo acclivata sp. nov. However, the presence of interocellar furrows in the latter (absent in Tenthredo picfa) make these species distinct from one another as well as Tenthredo kulwantae sp. nov. Some of the specific characters of this species include: clypeus pale whitish except base; pale are further: lateral margins of propodeum and posterior deltoid spot on apices of femur, tibia of mesoleg; clypeus circularly incised up to half of its length with rounded lateral teeth, and antenna filiform, $2.7 \mathrm{x}$ head width.

\section{Female}

Colour: Body black, pale whitish are: clypeus except base, labrum except margins, mandible barring apex, triangular spot touching eye on lower hind orbit; posterodorsal, posterolateral and ventral margins of pronotum; inner and outer margins of tegula, ridges lateral to scutelli, lateral margins of mesoscutellar appendage, dim spot behind metascutellum; posterior and lateral margins of propodeum, deflexed lateral sides of tergite four confluencing with its narrow anterior stripe, tergite nine except lateral sides; anterior aspect of proleg, posterior deltoid spot on apices of femur and tibia of mesoleg. Wings hyaline with infuscated crossband over stigma on forewing, venation including costa, subcosta and stigma fuscous.

Structure: Average length $7.0 \mathrm{~mm}$. Antenna filiform, $2.7 \mathrm{x}$ head width, flagellum not compressed, scape and pedicel as 4.0:3.0, segments three and four almost equal; clypeus circularly incised upto $1 / 2$ of its length with rounded lateral teeth; labrum broader than long as 4:3 with rounded anterior margin, malar space $0.3 \mathrm{x}$ diameter of median ocellus; LID:IDMO:EL=1.0:2:1.9, POL: OCL: $\mathrm{OOL}=1.0: 1.3: 1.6$; frontal area below level of eyes, median fovea narrowly canaliculate, shallowly reaching median ocellus, and laterally limited by slightly indicated supraantennal tubercles confluenting with low lying frontal ridges; post-, inter- and circumocellar furrows absent; lateral furrows pit-like, diverging posteriorly; postocellar area convex, wider than long as 2:1 and without transverse hind carina; head narrowing behind eyes; ICD:ITD=1.0:3.0; mesoscutellum subconvex, its appendage ecarinate; mesepisternum obtusely round, mesosternum lacking thorns; metafemur longer than metatibia, metabasitarsus equal to following three joints combined, tarsal claw with subapical tooth almost equal to apical one; IATS:MB:OATS $=1: 1.8: 0.75$. Lancet (Fig. 38) having 22 serrulae. 


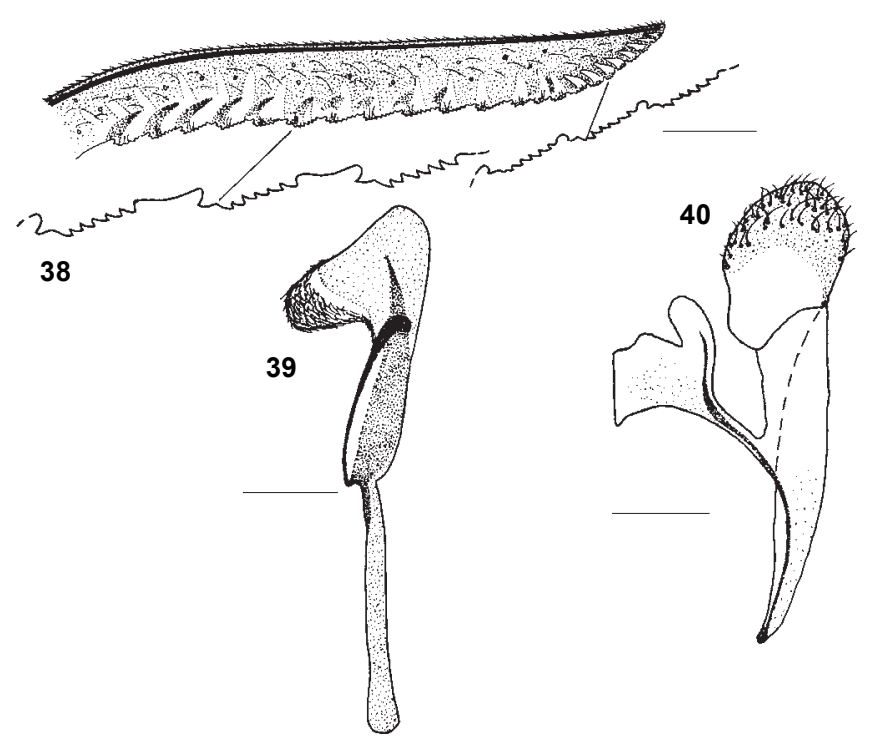

Figs. 38-40. Tenthredo picfa sp. nov.

38 - Lancet; 39 - Penis valve; 40 - Gonoforceps. Scale $=1.0 \mathrm{~mm}$

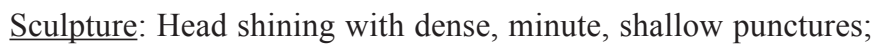
mesonotum shining with dense, minute, distinct punctures; mesoscutellum and appendage almost impunctate; mesepisternum opaque with dense, minute, almost confluencing punctures; mesosternum densely punctulate; abdomen shining with dense, fine punctures.

\section{Pubescence: Silvery, $0.15 x$ scape length.}

\section{Male}

Length $6.0 \mathrm{~mm}$. Similar to female except pale whitish in addition are: clypeus and labrum entirely; anterior aspect of proleg entirely, anterior aspect of mesoleg except tibia and tarsi, ventral stripe on metafemur, broad anterior margin of tergite three, anterior $1 / 2$ of tergite four, deflexed lateral sides of tergites two to five and corresponding sternites entirely. Genitalia: Penis valve (Fig. 39), gonoforceps (Fig. 40).

\section{Remarks}

This medium sized species of pompilina-complex is widely distributed almost all along the southernslopes of Himalaya. We collected this species taking it as Tenthredo pompilina Malaise but later on it got differentiated from the latter because of its distinct specific characters. Like Tenthredo pompilina it also frequently sits on the broad leathery leaves of Plantago major (Plantaginaceae) but whether the latter is its host plant or not remains to be ascertained. In most of the behavioural characteristcs and ecological adaptations this species is very closely allied to Tenthredo pompilina Malaise.

\section{Tenthredo acclivata sp. nov.}

(Figs. 41-43)

\section{Material examined}

Holotype: Female, 26.vi.1992, Rana, Uttaranchal, 1800m, coll. M.S. Saini.

Paratypes: One female, 22.v.1985, Flower Valley, Uttaranchal, coll. M.S. Saini; one female, 13.vi.1985, Chopta, 2600m, coll. M.S. Saini; two females, one male, 28.vi.1991, Kunjkharag, 2600m, coll. V. Vasu; one female, one male, 11.vii.1991, Kalatop, Himachal Pradesh, 2400m, coll. V. Vasu.

Individual variations: All specimens alike.

\section{Distribution \\ India: Himachal Pradesh, Uttaranchal.}

\section{Etymology}

Species name pertains to gradual size of median fovea towards median ocellus.

\section{Diagnostic features}

On the basis of a group of characters such as interocellar furrows present, circumocellar furrows absent, antennal segment three almost equal to four, subapical tooth of tarsal claw equal to apical one and abdomen coal black above, Tenthredo acclivata sp. nov. and Tenthredo kulwantae sp. nov. form a distinct subgroup within pompilina-complex of the sawflies. However, some of their specific characters such as: interocellar furrows distinct in Tenthredo acclivata (shallow in Tenthredo kulwantae), clypeus incised up to half of its length in Tenthredo acclivata (1/3 in Tenthredo kulwantae), scape and pedicel as 2:1 in Tenthredo acclivata (4:3 in Tenthredo kulwantae) and mesofemur almost entirely black in Tenthredo acclivata (anterior aspect of mesofemur entirely pale in Tenthredo kulwantae) make them distinct from each other.

\section{Female}

Colour: Body black, pale whitish are: clypeus except base, labrum except margins, mandible barring apex, deltoid spot on lower hind orbit touching eye; posterodorsal, posterolateral and anterolateral margins of pronotum, outer and inner margins of tegula, lateral sides of mesoscutellar appendage, spot behind metascutellum; narrow hind margin and broad lateral aspects of propodeum; anterior half confluent with broad lateral aspects of tergite four, tergite nine except anterolateral angles; hind margins of sternites four to five; anterior aspect of proleg, anterior spots on apices of femur and tibia of mesoleg, apex of metacoxa. Wings hyaline with infuscated crossband over stigma on forewing, venation including costa, subcosta and stigma fuscous to black.

Structure: Average length $8.0 \mathrm{~mm}$. Antenna $3 \mathrm{x}$ head width, flagellum with apical five segments faintly compressed, scape and pedicel as 2.0:1.0, segments three and four almost equal; clypeus roundly incised up to half of its length with rounded lateral teeth, labrum broader than long as 5:4 with rounded anterior margin; malar space $0.5 \mathrm{x}$ diameter of median ocellus; 


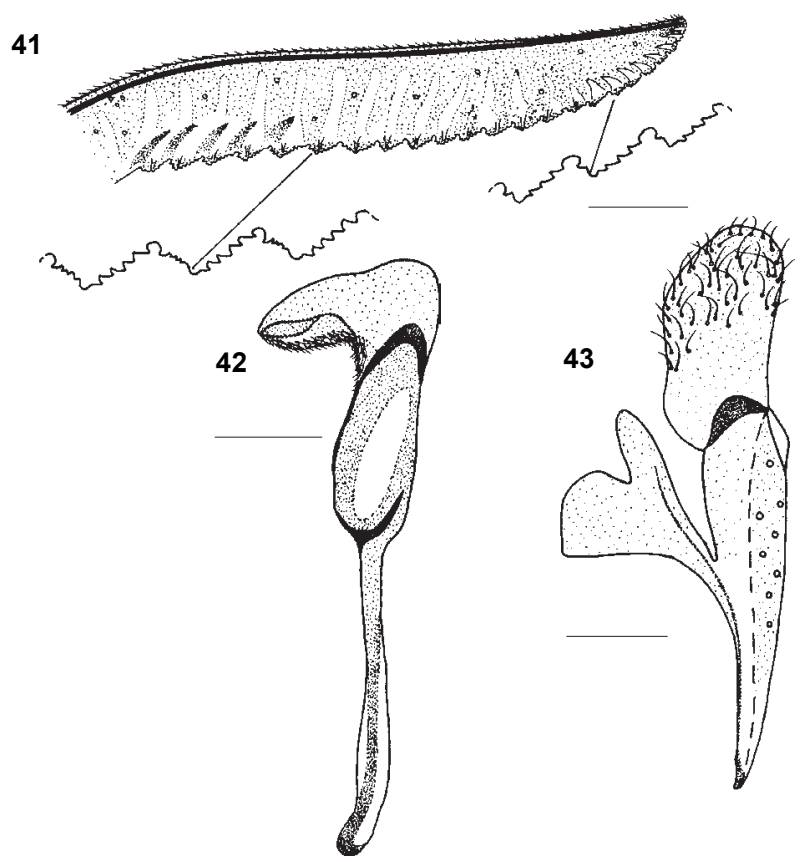

Figs. 41-43. Tenthredo acclivata sp. nov. 41 - Lancet; 42 - Penis valve; 43 - Gonoforceps. Scale $=1.0 \mathrm{~mm}$

LID:IDMO:EL=1.0:1.5:1.5, POL:OCL:OOL=1.0:1.6:1.8; frontal area below level of eyes; median fovea deep anteriorly, posteriorly shallowly reaching median ocellus; supraantennal tubercles moderately raised and posteriorly confluenting with insignificant frontal ridges; post- and circumocellar furrows absent, interocellar one deep and distinct; lateral furrows deep, almost parallel; postocellar area convex, wider than long as 4:3; head narrowing behind eyes; ICD:ITD $=1: 3$, mesoscutellum subconvexly round, its appendage carinate; mesepisternum obtusely round, mesosternum lacking thorns; metafemur longer than metatibia, metabasitarsus almost equal to following three joints combined; tarsal claw with subapical tooth almost equal to apical one; IATS:MB:OATS = 1.0:1.5:0.75. Lancet (Fig. 41) having 22 serrulae.

Sculpture: Head shining, with dense, fine, inconspicuous punctures; mesonotum with dense, minute, distinct, shallow punctures; mesoscutellum with large, scattered punctures on posterior slope, its appendage wrinkled; mesepisternum with dense, minute, almost confluenting punctures, surface opaque; mesosternum densely punctulate; abdomen faintly microstriated with fine inconspicuous punctures, surface shining.

Pubescence: Silvery, $0.15 x$ scape length.

\section{Male}

Average length $7.0 \mathrm{~mm}$. Similar to female excepting the crossband below stigma faint. Genitalia: Penis valve (Fig. 42), gonoforceps (Fig. 43).

\section{Remarks}

This species is well represented in nature, particularly in the upper ranges of northwestern Himalaya. In overall appearance, habitat, behaviour and ecological adaptations (particularly in the field) this species is quite close to Tenthredo pompilina Malaise but their minute and detailed studies reveal the specific differences. Like Tenthredo pompilina its flight period extends upto end of monsoon season (i.e. end of July) but this happens in the areas of low altitude only. In high altitude regions it comes to an end upto the last week of June. This species does not have any specific liking for any specific plant.

\section{Tenthredo kulwantae sp. nov.}

(Figs. 44-46)

\section{Material examined}

Holotype: Female, 1.vi.1991, Himachal Pradesh, Solang Valley, 2700m, coll. M.S. Saini.

Paratypes: Three females, 24.vii.1982, Kalatop, Himachal Pradesh, 2400m, coll. M.S. Saini; one male, 26.vi.1991, Kalamunitop, Uttaranchal, 2700m, coll. M.S. Saini.

Individual variations: All specimens alike.

\section{Distribution}

India: Uttaranchal, Himachal Pradesh.

\section{Etymology}

Species is named in honour of Dr. Kulwant Kaur, wife of the first author, Dr. M.S. Saini.

\section{Diagnostic features}

Tenthredo kulwantae sp. nov. is closely associated with Tenthredo acclivata sp. nov., but both can be set aside from one another as discussed under the latter.

\section{Female}

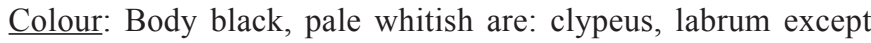
margins, mandible barring apex, deltoid spot touching eye margin on lower hind margin; posterodorsal, posterolateral and ventral margins of pronotum; inner and outer margins of tegula, ridges lateral to scutelli, spot behind metascutellum; extreme posterior and broad lateral margins of propodeum, narrow anterior margin of tergite four confluencing with its broad lateral sides, tergite 9 except lateral sides, posterior margins of sternites four to five, anterior aspect of proleg, anterior aspect of mesoleg except mesotibia which is more or less infumated, apex of metacoxa, inner lateral aspect of metatrochanter. Wings hyaline with infuscated crossband over stigma on forewing, venation including costa, subcosta and stigma fuscous.

Structure: Average length 7.0mm. Antenna filiform, 2.7x head width, flagellum not compressed, scape and pedicel as 4.0:3.0, segments three significantly shorter than four; clypeus circularly incised upto $1 / 3$ of its length, labrum broader than long as 4:3 with rounded anterior margin; malar space $0.8 \mathrm{x}$ diameter of median ocellus; LID:IDMO:EL=1.0:1.4:1.6, POL:OCL:OOL=1.0:1.2:1.6; frontal area below level of eyes; 
median fovea deep in anterior half and posteriorly not reaching median ocellus; supraantennal tubercles moderately raised and posteriorly confluenting with insignificant frontal ridges; postand circumocellar furrows absent, interocellar furrow shallow; lateral furrows distinct, bulging medially; postocellar area convex, wider than long as 5:3, without transverse hind carina; head narrowing behind eyes; ICD:ITD=1.0:3.0, mesoscutellum subconvex, its appendage carinate; mesepisternum obtusely round, mesosternum lacking thorns; metafemur longer than metatibia, metabasitarsus equal to following three joints combined, tarsal claw with subapical tooth almost equal to apical one; IATS:MB:OATS = 1:1.5:0.75. Lancet (Fig. 44) having 22 serrulae.

Sculpture: Head shining with dense, fine, shallow punctures; mesonotum with dense, minute, distinct punctures; mesoscutellum with large, scattered punctures on posterior half, appendage wrinkled; mesepisternum opaque with dense, minute, shallow, almost confluenting punctures; mesosternum densely punctulate; abdomen shining with faint microstriations and fine, inconspicuous punctures.

\section{Pubescence: Silvery, $0.15 x$ scape length.}

\section{Male}

Average length $6.5 \mathrm{~mm}$. Similar to female excepting whitish in addition are: labrum entirely, anterior aspects of coxa and trochanter of metaleg, ventral stripe on metafemur, broad anterior margin of tergite three, tergite four except nebulose medial spot on posterior margin, deflexed lateral sides of tergite two to five and corresponding sternites entirely. Genitalia: Penis valve (Fig. 45), gonoforceps (Fig. 46).

\section{Remarks}

In distribution this species is again similar to Tenthredo acclivata excepting one thing that it has extended its Eastern limits up to the upper ranges of West Bengal. Both the sexes are easily available though the population of females is comparatively less than males. As far as the availability of Tenthredo kulwantae and Tenthredo acclivata are concerned the former is available (i.e. comparatively more active) towards the mid hours of the day whereas the latter one can be seen throughout the day (i.e.even sometime after the sun-set). Flight period of both the species is almost same. Tenthredo kulwantae exhibits some predilection for the host plant of Tenthredo pompilina Malaise i.e. Plantago major, but its actual host plant is yet to be determined.

\section{REFERENCES}

Cameron, P. (1876). Descriptions of new genera and species of Tenthredinidae and Siricidae, chiefly from the East Indies, in the Collection of the British Museum. Part III. Transactions of theRoyal Entomology Society, London 1: 459-471.

Cameron, P. (1877). Descriptions of new genera and species of East Indian Tenthredinidae. Transactions of theRoyal Entomology Society, London 2: 87-92

Cameron, P. (1899). III. Hymenoptera Orientalia, or contributions to a knowledge of the Hymenoptera of the Oriental Zoological Region, Part VIII. The Hymenoptera of the Khasia Hills: First paper. Memoirs
44

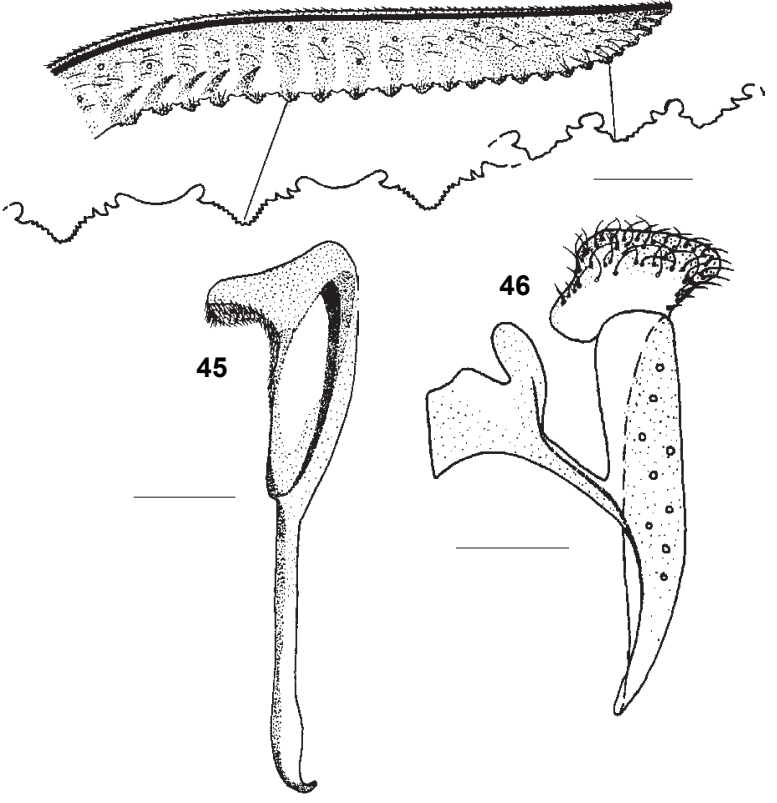

Figs. 44-46. Tenthredo kulwantae sp. nov. 44 - lancet; 45 - penis valve; 46 - gonoforceps. Scale = 1.0mm

and Proceedings of the Manchester Literary Philosophical Society 18981899 43(3): 1-220.

Cameron, P. (1902). Descriptions of new genera and species of Hymenoptera collected by Maj. C.S. Nurse at Deesa, Ferozpur, Simla, Part I. Journal of the Bombay Natural History Society 14: 419-449.

Forsius, R. (1931). Uber einige neue order wening bekannte orientische Tenthredinoiden. Ann. Mus. Wein. 46: 29-48.

Jakovlev, A. (1891). Diagnoses Tenthredinidarum novarum ex Rossia Europaea, Sibiria, Asia Media et confinum. Trudy Russk. ent. Obsc. (Horae Soc. ent. Ross) St. Petersburg, 26: 1-62.

Kirby, W.F. (1882). List of Hymenoptera with descriptions and figures of typical specimens in the British Museum, Vol. I. Tenthredinidae and Siricidae.Taylor and Francis, London, 8: 1-450, 16 pls.

Konow, F.W. (1898). Neue Chalastogastra-Gattungen und Arten. Entomologische Nachrichten 24(17-18): 268-282.

Konow, F.W. (1901). Neue Chalastogastra Arten. Terms. Fuzetek., 24: 57-72. Konow, F. W. (1903). Ueber neue order wenig bekannte Tenthrediniden (Hymenoptera) des Russischen Reiches und Centralasiens. Annuare du Musee Zoologique de l'Academie Imperiale des Sciences de Saint. Petersbourg 8: 115-132.

Konow, F.W. (1905). Hymenoptera, Fam. Tenthredinidae. In: P. Wytsman (Edn.), Genera Insectorum. Fasc. Brxelles 29: 176pp.

Konow, F.W. (1906). Einige neue Palaarktische und orientalische Tenthrediniden. Zeitschrift fur systematische Hymenopterologie und Dipterologie 6: 254: 256, 329-331.

Konow, F.W. (1907a). Neue Blattwespen (Hym.). Deutsche Entomologische Zeitschrift 51: 489-497.

Konow, F.W. (1908). Neue Tenthrediniden aus Sikkim (Hym.). Zeitschrift fur systematische Hymenopterologie und Dipterologie 8: 19-26.

Malaise, R. (1945). Tenthredinoidea of South-eastern Asia with a general Zoogeographical review. Opuscula Entomologica Supplement, iv: 288pp. Mocsary, A. (1883). Hymenoptera nova europea et exotica. Ertekezesek a termesettudomanyok Korebol 13(11): 1-72.

Muche, W. H. (1982). Beitrag zur Blattwespenfauna von Indien and Pakistan, mit Beschreibung einer neuen Art sowie Unterart (Hymenoptera, Symphyta, Tenthredinidae). Reichenbachia Mus. Tierk. Dresden 20(15): 113-117.

Muche, W. H. (1983). Die von Hern Dr. W. Wittmer in Indien and Bhutan gesammelten Blattwespen, mit Beschreibung von secks neuen 
Arten der Tenthrdinidae (Hymenoptera, Symphyta). Reichenbachia Mus. Tierk. Dresden 21(29): 167-180.

Muche, W.H. (1986). Beitrag zur Symphytenfauna von Nepal (Hymenoptera, Argidae et Tenthredinidae). Reichenbachia Mus. Tierk. Dresden 24(9): 79-90.

Radoszkowsky, O.deB. (1872). Hymenopteres de L 'Ase. Descriptions et enumerations de quelques especes recues de, Samarkand, Astraband, Himalaya, et-Ning-Poenchina. Hor. Ent. Ross, 8: 187-200.

Rohwer, S.A. (1915). Some Oriental sawflies in the Indian Museum (Hymenoptera). Records of the Indian Museum, Calcutta 11: 39-53.

Rohwer, S.A. (1916). Descriptions of new species of Hymenoptera. Proceedings of the United States National Museum 49(2105): 205-249. Rohwer, S.A. (1921). Notes on sawflies, with descriptions of new genera and species. Proceedings of the United States National Museum 59(2361): 83-109. Ross, H.H. (1937). A generic classification of the Nearctic sawflies (Hymenoptera: Symphyta). Illinois Biological Monographs 34: 1-173. Ross, H.H. (1945). Sawfly genitalia: Terminology and study techniques. Entomological News 56: 261-268.

Saini, M.S. and H. Bharti (1996). Addition of five new species to the Indian Tenthredo Linnaeus (Tenthredinidae, Hymenoptera) from Northwest India. Annals of Entomology 14(2): 61-67.

Saini, M.S. and H. Bharti (1997a). New additions to Indian Tenthredo from Northwestern Himalayas (Hymenoptera: Tenthredinidae)-2. Bulletin of Association of Zoologists 3(2): 15-21.

Saini, M.S. and H. Bharti (1997b). New Indian Tenthredo species (Hymenoptera: Tenthredinidae) from the North-estern Himalayas. Folia Entomologica Hungarica 53: 173-181.

Saini, M.S. and V. Vasu (1998a). New additions of Tenthredo L. to Indian fauna (Hymenoptera: Tenthredinidae). Journal of Entomology Research 22(2): 139-146.

Saini, M.S. and V. Vasu (1998b). Four new species of Tenthredo L. (Hymenoptera: Tenthredinidae) from India. Zoos' Print Journal 13(11): 22-26.

Saini, M.S. and V. Vasu (1999). New species of Tenthredo L. from India (Hymenoptera: Tenthredinidae). Polish Journal of Entomology 68(2): 133-142.

Saini, M.S. and V. Vasu (2001). Description of three new species of Tenthredo Linneaus from India (Hymenoptera: Symphyta: Tenthredinidae). Zoos' Print Journal 16(2): 411-417.

Saini, M.S., A.S. Chambal and V. Vasu (1998a). Studies on three species of Tenthredo Linnaeus (Hymenoptera : Tenthredinidae) from India. Journal Entomological Research 22(3): 265-272.

Saini, M.S., B. Singh and V. Vasu (1998b). Two new species of Tenthredo Linnaeus (Hymenoptera, Symphyta, Tenthredinidae: Tenthredininae) from India. Journal of Entomological Research 22(1): 55-60.

Singh, B. (1985). Sawflies of genus Tenthredo Linn. (Hymenoptera: Tenthredinidae) - two new species from Himachal Pradesh, India. Annals of Biology 1(2): 179-183.

Singh, B., S.S. Dhillon and T. Singh (1985a). Three new species of the genus Tenthredo Linn. (Tenthredinidae: Hymenoptera) from India. Entomon 10(3): 203-207.

Singh, B., T. Singh and S.S. Dhillon (1985b). Two new species of genus Tenthredo Linn. (Hymenoptera: Tenthredinidae) from Northwest Himalaya, India. Uttar Pradesh Journal Zoology 5(1): 37-41.

Singh, D. and M.S. Saini (1986). First record of 13 species of Tenthredo Linn. (Hymenoptera: Tenthredinidae) from India. Uttar Pradesh Journal Zoology 6(1): 75-81.

Singh, D. and M.S. Saini (1987a). Six new species Tenthredo Linn. from Northwestern India (Hymenoptera, Symphyta, Tenthredinidae). Reichenbachia Mus. Tierk. Dresden 24(29): 189-198.

Singh, D. and M.S. Saini (1987b). Six new species of Tenthredo Linn. (Hymenoptera: Tenthredinidae) from India. Journal of New York Entomological Society 95(2): 328-337.

Singh, D. and M.S. Saini (1987c). First record of males for fifteen Oriental species of Tenthredo Linn. (Hymenoptera: Tenthredinidae) from India. Entomon 12(3): 305-308.

Singh, D. and M.S. Saini (1987d). Five new species of Tenthredo Linnaeus from Uttarkhand area (India) (Hymenoptera: Tenthredinidae).
Deutsche Entomologische Zeitschrift 34(4-5): 397-405.

Singh, D. and M.S. Saini (1988a). Five new species of Tenthredo Linnaeus (Hymenoptera: Tenthredinidae) from the Garhwal Hills. Journal Bombay Natural History Society 85(1): 143-150.

Singh, D. and M.S. Saini (1988b). Six new species of Tenthredo Linn. from the Western Himalayas (Insecta, Hymenoptera, Symphyta, Tenthredinidae). Reichenbachia Mus. Tierk. Dresden 25(28): 137-147. Singh, D. and M.S. Saini (1988c). Six new species of Tenthredo Linnaeus (Hymenoptera: Tenthredinidae) from Northern India. Journal Bombay Natural History Society 85(2): 366-375.

Singh, D. and M.S. Saini (1988d). Five new species of Tenthredo Linnaeus from the Eastern Himalaya (Hymenoptera, Tenthredinidae). Deutsche Entomologische Zeitschrift 35(4-5): 387-394.

Singh, D. and M.S. Saini (1990). Transfer of species lucida from Macrophya to Tenthredo (Hymenoptera: Tenthredinidae). Journal of Entomological Research 14(1): 146.

Singh, D. and M.S. Saini (1994). Two new species of Genus Tenthredo Linn. (Hymenoptera: Tenthredinidae) from the North-western Himalaya. Uttar Pradesh Journal Zoology 14(2): 129-133.

Singh, D. and M.S. Saini (1995). New sawflies of the genus Tenthredo Linn. (Hymenoptera, Symphyta, Tenthredinidae) from India. Annals of Entomology 13(1): 9-13.

Smith, F. (1878). Scientific results of the 2nd Yarkand Mission. Based upon the collection and notes of the late F. Stolizka, Calcutta: Published by the order of the Government of India, 4-22.

Taeger, A. and S.M. Blank (1996). Kommentare zur Taxonomie der Symphyta (Hymenoptera). Beitr. Ent. 46(2): 251- 275.

Togashi, I. (1987). Indian sawflies of the genus Tenthredo (Hymenoptera, Symphyta) collected by the expedition of Zoologiske Museum, Copenhagen. Kontyu 55(1): 51-58.

Vasu, V. (1998). Two new synonymies of Tenthredo Linnaeus (Hymenoptera: Tenthredinidae). Journal of Entomological Research 22 (4): 387-388. New Delhi.

Vasu, V. (2000). A new synonymy for Tenthredo valvicepta Singh \& Saini (Hymenoptera: Tenthredinidae: Tenthredininae). Journal of Entomological Research 23(3): 215-217.

Vasu, V. and A.S. Chambal (1997). New synonymy for Tenthredo subflava Malaise (Hymenoptera: Tenthredinidae). Journal of Entomological Research 21(4): 385-388.

Vasu, V. and A.S. Chambal (1998a). New record of females of two species of Tenthredo Linnaeus (Hymenoptera: Tenthredinidae). Journal of Entomological Research 22(1): 97-99.

Vasu, V. and A.S. Chambal (1998b). A new synonymy for Tenthredo dorsivittata (Cameron) (Hymenoptera: Tenthredinidae). Journal of Entomological Research 22(4): 313-317.

Vasu, V. and M.S. Saini (1997). Description of Tenthredo floweri Singh and Saini (Hymenoptera: Tenthredinidae). Insect Envioronment 3 (2): 35-36.

Vasu, V. and M.S. Saini (1998). Studies on four species of Tenthredo Linnaeus from Burma and the Indian subcontinent (Insecta: Hymenoptera: Tenthredinidae: Tenthredininae). Reichenbachia Mus. Tierk. Dresden 32(42): 291-298.

Vasu, V. and M.S. Saini (1999a). Three new species of the genus Tenthredo L. from India (Hymenoptera: Tenthredinidae). Polish Journal of Entomology 68(2): 143-150.

Vasu, V. and M.S. Saini (1999b). A new synonym of Tenthredo zebra Konow, 1898 (Hym., Tenthredinidae). Entomologist's monthly Magazine 135(7): 111-114.

\section{ACKNOWLedgements}

The authors are highly thankful to Dr. D.R. Smith, U.S. Department of Agriculture, Washington, D.C., USA, for his valuable suggestions. Financial assistance rendered by US, PL-480 in coordination with ICAR, New Delhi is sincerely acknowledged. 


\section{Key to the species of pompilina complex of Tenthredo Linnaeus}

1. Forewings with distinct infuscated band over stigma or only second cubital cell infuscated ..................................................... 2

1A. Forewings either clear, hyaline, or infuscated at apex, but without infuscated band over stigma other species of Tenthredo Linnaeus

2. Forewings with infuscated band over stigma 3

2A. Forewings with only second cubital cell infuscated; (Antenna 2.5x head width, scape and pedicel as 4.0:3.0, segment three shorter than four; postocellar area wider than long as $4: 3$, with distinct transverse carina on hypothetical hind margin of head; postocellar furrows absent, lateral furrows parallel; median fovea broad, shallow and clearly reaching median ocellus) .............................................. Tenthredo infucubitus sp. nov.

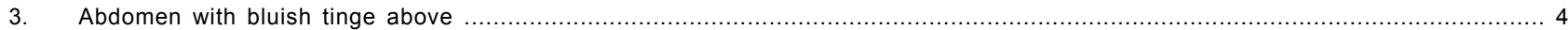

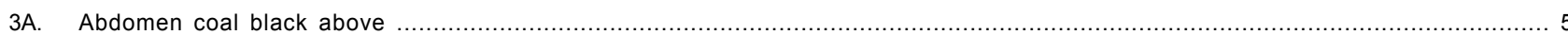

4. Wing apex hyaline beyond crossband; antenna long, 3.2x head width, segment three shorter than four; mesonotum densely punctate; mesoscutellum carinate and with large, deep, dense, distinct punctures; mesopleura rugose with confluenting punctures; frontal ridges with dense, minute punctures

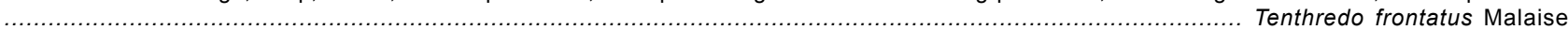

4A. Wing apex infumated beyond crossband; antenna short, $2.5 \mathrm{x}$ head width, segment three longer than four; mesonotum impunctate; mesoscutellum ecarinate and with large, shallow, few, scattered punctures; mesopleura rugose on lower half and with dense, distinct punctures on upper half of convexity of mesepisternum; frontal ridges almost impunctate ............................................................... Tenthredo pseudofrontatus Singh \& Saini

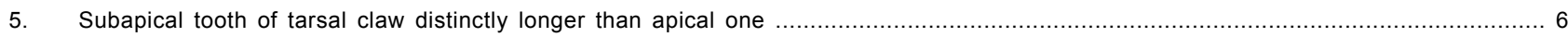

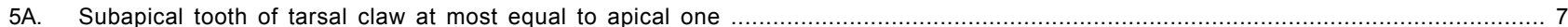

6. Abdomen fuscous except pale whitish deflexed latter sides of tergites two to four and corresponding sternites; antenna long, equiform, $3 x$ head width; clypeus subrectangularly incised; circumocllar furrow absent; median fovea broad canaliculate and shallowly reaching median ocellus; frontal ridges broad and with dense, large, confluenting punctures ....................................................... Tenthredo fuscoventris sp. nov.

6A. Abdomen black with anterior half of tergite four pale; antenna comparatively short, some apical segments compressed, $2.4 \mathrm{x}$ head width; clypeus circularly incised; circumoclar furrow distinct; median fovea deep ditch-like and clearly reaching median ocellus; frontal ridges narrow and with dense,

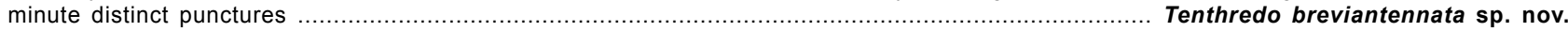

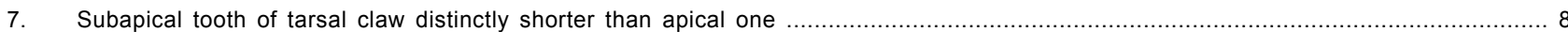

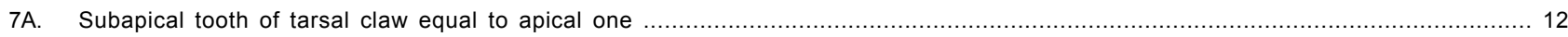

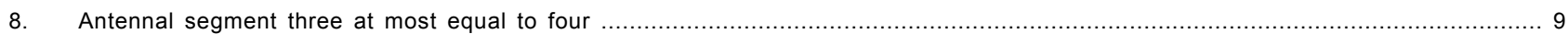

8A. Antennal segment three distinctly longer than four 10

9. Median fovea shallowly reaching median ocellus; circumocellar furrow shallow, interocellar furrow distinct; mesoscutellum impunctate, appendage faintly carinate; all femora, tegula and posterior angles of pronotum black more or less at least in female; postocellar area wider than long as $2: 1$; antenna short, $2.3 x$ head width; mesopleura rugose with minute, isolated punctures ...................................................... Tenthredo dif sp. nov.

9A. Median fovea distinctly reaching median ocellus; circumocellar furrow distinct, interocellar furrow absent; mesoscutellum distinctly punctate, its appendage distinctly carinate; all femora, tegula and posterior angles of pronotum pale yellow; postocellar area wider than long as 3:2; antenna long, $3 x$ head width; mesopleura rugose with large, confluenting punctures .................................................................... Tenthredo ifa sp. nov.

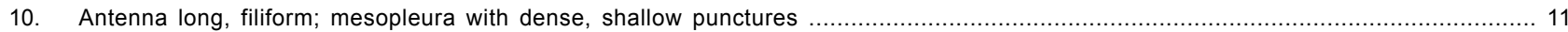

10A. Antenna short, clavate; mesopleura rugose with pit-like confluenting punctures; (wings hyaline with infumated apices; antenna $1.2 x$ head width, scape and pedicel as 4:3, segments 3 and 4 as 2:1; malar space $0.6 x$ diameter of median ocellus in female but linear in male; median fovea obsolete; lateral furrows diverging posteriorly; postocellar area wider than long as 4:3; mesoscutellum with median longitudinal carina on posterior slope, appendage carinate; head with dense, minute, deep, distinct punctures except frontal area with confluent punctures; mesonotum with dense, fine, shallow punctures; mesepisternum rugose, interspaces with dense, minute, shallow, confluent punctures ..................................... Tenthredo dalhousiensis Singh et al.

11. Postocellar area wider than long as 3:2; antenna with scape and pedicel as 2:1, segments three and four as 5:4; clypeus circularly incised; malar space $0.3 x$ diameter of median ocellus; mesoscutellum flat, rugose, its appendage ecarinate; head with large, confluent punctures; median fovea distinctly reaching median ocellus; mesopleura opaque; metabasitarsus equal to following three joints combined ....... Tenthredo santokhi Singh \& Saini

11A. Postocellar area wider than long as 2:1; antenna with scape and pedicel as 4:3, segments three and four as 4:3; clypeus rectangularly incised; malar space $0.75 x$ diameter of median ocellus; mesoscutellum convex, impunctate, its appendage ecarinate; head with minute, distinct punctures median fovea shallowly reaching median ocellus; mesopleura shining; metabasitarsus shorter than following three joints combined

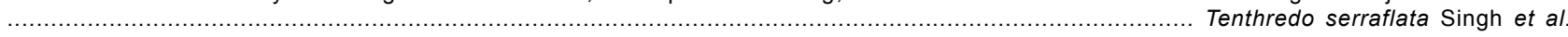

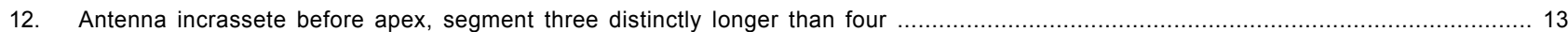

12A. Antenna aequiform, segment three at most equal to four 14

13. All tibiae and tarsi black; mesopleura entirely rugose; median fovea broad ditch-like and distinctly reaching median ocellus; antennal segments 3 and 4 as $4: 3$, scape and pedicel as $4: 3 ; \mathrm{OOL}: \mathrm{POL}=1.0: 2.0$ Tenthredo foveolata sp. nov.

13A. All tibiae and tarsi fuscous; ventral half of mesopleura rugose on posterior half with deep, large, scattered punctures intermingled with minute confluenting punctures; median fovea narrow ditch-like and broadly shallowly reaching median ocellus; antennal segments 3 and 4 as $3: 2$, scape and 
14A. Antennal segment three distinctly shorter than four (metatarsi brownish with apices infuscated; antenna filiform, 2.6x head width, scape and pedicel as 3:2, segments 3 and 4 as $8: 9$; malar space $0.6 x$ diameter of median ocellus; median fovea distinctly reaching median ocellus; postocellar furrow absent; lateral furrows bulging medially; postocellar area wider than long as 3:2; mesoscutellum pulvinate, appendage carinate; head with dense, minute, shallow punctures; mesoscutellar appendage minutely wrinkled; mesepisternum rugose, more so along convexity; mesosternum punctulate

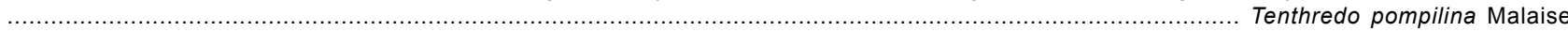

16. Entire clypeus, posterior and lateral margins of propodeum pale whitish; scape and pedicel as 5:3, clypeus with rounded lateral teeth, median fovea ecarinate, lateral furrows parallel, postocellar area wider than long as $7: 4$, metabasitarsus shorter than following three joints combined

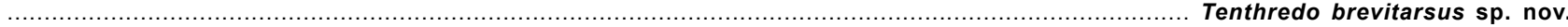

16A. Clypeal base, propodeum except pale lateral dot black; scape and pedicel as 5:4, clypeus with truncate lateral teeth, median fovea with carinate in its anterior half, lateral furrows bulging medially, postocellar area wider than long as 3:2, metabasitarsus equal to following three joints combined

Tenthredo equitarsus sp. nov.

17. Interocellar furrow present

17A. Interocellar furrow absent; (clypeus circularly incised; malar space $0.3 x$ diameter of median ocellus; median fovea narrowly canaliculate and shallowly reaching median ocellus; post-, inter- and circumocellar furrows absent; lateral furrows pit-like, diverging posteriorly; postocellar area wider than long as 2:1 and without transverse hind carina; antenna 2.7x head width, scape and pedicel as 4:3; head with dense, minute, shallow punctures; mesoscutellum and its appendage almost impunctate; mesepisternum opaque with dense, minute, almost confluenting punctures; mesosternum densely punctulate)

Tenthredo picfa sp. nov.

18. Interocellar furrow distinct; clypeus incised upto $1 / 2$ of its length; median fovea shallowly reaching median ocellus; lateral furrows almost parallel; scape and pedicel as 2:1; mesofemur almost entirely black, basal $1 / 2$ of anterior aspect may be pale Tenthredo acclivata sp.nov.

18A. Interocellar furrow shallow; clypeus incised up to $1 / 3$ of its length; median fovea not reaching median ocellus; lateral furrows bulging medially; scape and pedicel as 4:3; anterior aspects of mesofemur entirely pale 